
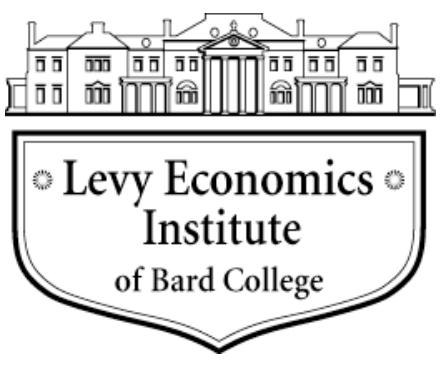

Working Paper No. 758

\title{
How the Fed Reanimated Wall Street: \\ The Low and Extended Lending Rates that Revived the Big Banks
}

by

\author{
Nicola Matthews \\ University of Missouri-Kansas City
}

March 2013

The Levy Economics Institute Working Paper Collection presents research in progress by Levy Institute scholars and conference participants. The purpose of the series is to disseminate ideas to and elicit comments from academics and professionals.

Levy Economics Institute of Bard College, founded in 1986, is a nonprofit, nonpartisan, independently funded research organization devoted to public service. Through scholarship and economic research it generates viable, effective public policy responses to important economic problems that profoundly affect the quality of life in the United States and abroad.

\author{
Levy Economics Institute \\ P.O. Box 5000 \\ Annandale-on-Hudson, NY 12504-5000 \\ http://www.levyinstitute.org
}

Copyright (C) Levy Economics Institute 2013 All rights reserved

ISSN 1547-366X 


\begin{abstract}
Walter Bagehot's putative principles of lending in liquidity crises - to lend freely to solvent banks with good collateral but at penalty rates - have served as a theoretical basis for thinking about the lender of last resort for close to 100 years, while simultaneously providing justification for central bank real-world intervention. If we presume Bagehot's principles to be both sound and adhered to by central bankers, we would expect to find the lending by the Fed during the global financial crisis in line with such policies. Taking Bagehot's principles at face value, this paper aims to examine one of these principles - central bank lending at penalty rates - and to determine whether it did in fact conform to this standard. A comprehensive analysis of these rates has revealed that the Fed did not, in actuality, follow Bagehot's classical doctrine. Consequently, the intervention not only generated moral hazard but also set the stage for another crisis. This working paper is part of the Ford Foundation project "A Research and Policy Dialogue Project on Improving Governance of the Government Safety Net in Financial Crisis" and continues the investigation of the Fed's bailout of the financial system - the most comprehensive study of the raw data to date.
\end{abstract}

Keywords: Lender of Last Resort; Global Financial Crisis; Monetary Policy; Fed Lending Rates; Bagehot's Classical Doctrine; Fed Emergency Credit and Liquidity Facilities

JEL Classifications: E4, E5, G1 


\section{INTRODUCTION}

The original impetus for the creation of the Federal Reserve (Fed) in 1913 was to safeguard the banking system from periodic liquidity crises. In so doing, it would act as the "lender of last resort" (LOLR) for depository institutions and provide reserves on demand. Traditionally, the Fed has fulfilled this responsibility by using two basic tools — open market operations and/or providing access to the discount window. And following suit, as the recent global financial crisis (GFC) unfolded in 2007, the Fed engaged in a series of repurchase agreements. In addition, it began cutting its rate at the discount window. However, as the GFC wore on, these tools would prove to be ineffective in resolving what it thought to be a liquidity crisis. ${ }^{1}$ As a result, the Fed developed many new and unconventional programs - each with their own lending rates - in an attempt to stabilize the GFC. While much has been made of the intervention itself, little research has been conducted solely on the lending rates.

The conventional wisdom on these matters typically dates back to the early nineteenth century. Among the first to draw attention to the role of the central bank (CB) as an LOLR was Henry Thornton (1802), followed by Walter Bagehot (1873). ${ }^{2}$ In more recent times, debate has ensued over the set of principles that Bagehot, in particular, advocated. These were that the $\mathrm{CB}$ should lend freely in times of crisis, but should do so at penalty rates; that it should lend against good collateral, and that it should do so to solvent banks only. One of Bagehot's more commonly cited passages illustrates these points:

[Advances, or loans by a central bank], if they are to be made at all, should be made so as if possible to obtain the object for which they are made. The end is to stay the panic... [and] for this purpose there are two rules: First. That these loans should only be made at a very high rate of interest...Secondly. That at this rate these advances should be made on all good banking securities, and as largely as the public ask for them. The reason is plain. The object is to stay alarm, and nothing therefore should be done to cause alarm. But the way to cause alarm is to refuse someone who has good security to offer...The amount of bad business in commercial countries is an infinitesimally small fraction of the whole business. That in a panic the bank, or banks, holding the ultimate reserve should refuse bad bills or bad securities will not make the panic really worse; the 'unsound' people are a feeble minority, and they are afraid even to look frightened for fear their

\footnotetext{
${ }^{1}$ The failure of the traditional tools can be attributed to, in part, institutional changes within the financial industry. Particularly the change from a bank-loan dominated financial industry to a capital-markets dominated industry. See Ricks (2011).

${ }^{2}$ Henry Thorton, An Enquiry into the Nature and Effects of the Paper Credit of Great

Britain, (London: Hatchard, 1802); Walter Bagehot, Lombard Street: A Description of the Money Market (London: S. King and Co., 1873).
} 
unsoundness may be detected. The great majority, the majority to be protected, are the 'sound' people, the people who have good security to offer. If it is known that the Bank of England is freely advancing on what in ordinary times is reckoned a good security — on what is then commonly pledged and easily convertible - the alarm of the solvent merchants and bankers will be stayed. (Bagehot 1873, sections VII.58-59, emphasis added)

Although such well-known economists as Robert Solow and Andrew Crockett (along with others) have supported the commonly received notion that the CB should lend at penalty rates in times of liquidity crises, it has been argued elsewhere that Bagehot, in fact, never intended such a policy, nor did he use the actual word penalty anywhere in Lombard Street (Solow 1982, 237-48; Crockett 1997). ${ }^{3}$ Instead, Bagehot used the terms high or very high rate as is evident in the passage above. The reason is two-fold: one, Bagehot was addressing banking crises under the conditions of a gold standard; and two, he was writing during a time when usury laws were in effect. Regarding the former, it was necessary to keep the rates high to avoid a foreign drain rather than penalize banks. In other words, Bagehot was addressing the need to maintain gold reserves in the face of a panic. As for the latter, given the law, it was not feasible to increase rates much beyond 5 percent, where rates of 6 to 7 percent were considered to be very high. ${ }^{4}$ In light of these conditions, it is not entirely clear if Bagehot would have recommended penalty rates without the problem of a foreign drain.

Despite these arguments, Bagehot's principles have been interpreted in a multitude of ways. One such interpretation can be found in a recent paper by Cecchetti and Disyatat (2010). In it, they argue that the rate policy should be predicated on the type of liquidity shortfall. That is, that the type of liquidity shortfall should condition the support provided. For instance, in a systemic event, lending by the Fed should be undertaken at "an effectively subsidized rate compared to the market rate while taking collateral of suspect quality" (Cecchetti and Disyatat $2010,14)$. In the occurrence of what they call a "simple shortage" — institutionally specific Bagehot's principles should hold. Yet, regardless of the various interpretations, it is clear that

\footnotetext{
${ }^{3}$ Although Solow and Crockett pay heed to Bagehot's classical doctrine, it must be noted that they were in some measure mindful of the problems that arise from a LOLR — such as the problem of deciphering illiquidity from insolvency. However, both were explicit in the role of penalty rates as Solow makes clear: "the penalty rate is a way of reducing moral hazard" (Solow 1982, 247). For a more comprehensive analysis on Bagehot and the penalty rate issue, see Moe (forthcoming).

${ }^{4}$ See Goodhart and Illing (2002). "[B]oth Thornton and Bagehot were aware of the need to raise interst rates to check a foreign drain of gold from the bank. But Thornton's lack of emphasis on this point may well have been due to the continuing effect of the usury laws, in force until the 1830's, capping (formal) interest rates at 5\% and preventing the bank from using this instrument aggressively in a crisis" (Goodhart 2002, 228).
} 
the dominant perspective has been to lend at penalty rates and against good collateral. Bagehot's principles of lending in liquidity crises, has served as a theoretical basis for thinking about LOLR for close to a 100 years while simultaneously providing justification for central bank real world intervention.

Thus, if we presume Bagehot's principles to be sound and followed by central bankers, we would expect to find the lending by the Fed during the GFC in line with such policies. In assessing the GFC and the Fed's response under the conventional wisdom initially put forth by Bagehot, there are two questions of concern. One, did the Fed lend at penalty rates and two, did it lend on good collateral? If no on both counts, there are several consequences to consider. The first is whether the GFC can then be interpreted as a solvency crisis as opposed to a liquidity crisis. ${ }^{5}$ Second, would not the Fed lose its credibility as well as generate moral hazard? Third, do such actions on the part of the Fed encourage banks to increase risk? And finally, insolvent banks are not supposed to be candidates for LOLR; rather, they are candidates for resolution, which is under the purview of the Treasury, not the Fed (Todd 2002).

Taking Bagehot's principles at face value, the aim of this paper is to examine the lending rates that the Fed set during the GFC for the majority of the programs it created as well as the rates that individual institutions received (it is beyond the scope of this paper to research the issue of collateral) and to determine whether these rates conformed to Bagehot's recommendation. That is, did the banks, and especially the larger banks, benefit from Fed rates that were lower than market rates and in doing receive an implicit subsidy? Although the Fed created 13 facilities and/or programs over the course of the GFC, we will concentrate on eight of these plus an additional open market operation that was undertaken at the height of the crisis. The reasons behind the exclusion of the remaining five facilities are as follows: the first, Liquidity Swap Lines, were currency swaps with other central banks and not depository or investment institutions; three of the facilities would never become operational (the Money Market Investor Funding Facility and direct funding on future principle losses to Citigroup and Bank of America); and the fifth facility, the Agency Mortgage-Backed Securities Program, undertook outright asset purchases, not loans. The focus, then, will be to determine, based upon the conventional wisdom, whether or not the Fed lent at penalty rates.

\footnotetext{
${ }^{5}$ Despite the complication in distinguishing between illiquidity and insolvency, the low rates, the length of lending during the GFC, and the outright purchase of $\$ 1.25$ trillion in mortgage-backed securities supports an argument for insolvency.
} 
By and large, the daily borrowing that took place from the Fed facilities throughout the GFC by depository and non-depository financial institutions had relatively short durations with the exception of the direct support provided to institutions and those directed at the credit markets. Thus, in terms of methodology, there are two ways of measurement when it comes to assessing the overall level of intervention by the Fed - cumulative (related to flows of lending over time) and outstanding (related to stocks at a point in time). There has been some recent controversy over these different forms of measurements. ${ }^{6}$ Despite this, it must be noted that neither measurement is necessarily right or wrong. Rather, they depend upon the type of question asked. A simple way of deciphering whether a cumulative measure is relevant is to ask if there is significance in the number and size of transactions undertaken in each facility. If this number is relevant, which I argue it is, it is also important to have a measure of cumulative amounts. This dual approach, stocks plus flow measures, not only recognizes the differences between stocks and flows but also underscores the fact that the measurements give diverging descriptions of the crisis. An analogy will serve to illuminate this point.

Consider a swimming pool that has developed massive cracks in its basin and will empty of water if not repaired. At the same time, however, it is desired that the pool should continue to maintain a level of water that is suitable for swimming. But because it takes time to restore the cracks, you would need to have massive amounts of water injected daily to keep the water level in the pool around a given accepted level. ${ }^{7}$ This level may vary from day to day, but only negligibly. In this scenario, the pool, then, is losing water and gaining water at a rate that is close to what is needed to maintain an acceptable level for swimming. Measuring this level on a daily basis would give you the stock of water at points in time but it says nothing of how much water was needed to keep it at that level. That is, it does not measure the real magnitude of the structural failure in the pool basin. If we want to know the severity of the failure, measuring the level of water as a stock will hardly give us the most critical answer. For instance, imagine there were two pools with exact dimensions and both with structural failures. Yet, one of the pools is damaged much more severely than the other. The rate of water needed to maintain the same level in both pools on a day-to-day basis would clearly be quite different. Measuring the flow of water gives the magnitude and provides a gauge for the severity of the failure. Thus, it matters

\footnotetext{
${ }^{6}$ See Ivry, Keoun, and Kuntz (2011); Bernanke (2011); Bloomberg News (2011); Felsenthal (2011); Wray (2011); and Felkerson, (2011).

${ }^{7}$ To make this metaphor closer to reality, we would also have to assume that all the water lost from the pool was recycled back into the device which pumped the water in.
} 
how many times depository and investment institutions accessed the Fed's facilities and how much was borrowed each time. We can measure the magnitude by the total amount of transactions and by the cumulative amounts borrowed. ${ }^{8}$

Furthermore, because this paper focuses on the rates the Fed provided, we will be using the cumulative amounts, as these reflect each transaction undertaken and provides us with a more accurate account of each rate. ${ }^{9}$ The loan duration of many of the facilities spanned from 24 hours to 84 days. To capture the most accurate account of the interest charged, it is crucial to look at each loan. The rates reported are taken from the Federal Reserve's website and are presented in a mean form. ${ }^{10}$ The disclosure of the 21,000-plus transactions that can be found on the website was the result of the passage of the Dodd-Frank Wall Street Reform and Consumer Protection Act of 2010. The structure of this paper is as follows: Section 2 examines the rates received by depository and investment institutions, Section 3 examines the rates to Bear Sterns and American International Group, Section 4 inspects the rates designed for the credit markets, Section 5 will summarize and analyze multiple market rates, and Section 6 will contain the conclusion.

\section{TAF, ST OMO, TSLF, AND PDCF: SHORT-TERM LIQUIDITY SUPPORT TO DEPOSITORY AND INVESTMENT INSTITUTIONS}

\subsection{TAF}

As the GFC developed in the latter part of 2007, liquidity began to tighten, specifically in the short-term funding markets. As a consequence, there was a need on the part of banks to find alternative methods of financing. One such method is to use the Federal Reserve's (Fed's) discount window. However, banks were wary of accessing it for fear of the "stigma problem.",11 As a method of sidestepping this and addressing the liquidity shortfall, the Fed created the Term Auction Facility (TAF) in December 2007. ${ }^{12}$ The structure of the TAF was designed quite differently from discount window borrowing. Instead of banks directly going to the discount

\footnotetext{
${ }^{8}$ See, also, Felkerson (2012).

${ }^{9}$ For more information on the Fed's response to the GFC, see GAO (2011) and Wray (2012).

${ }^{10}$ Data on the Fed's credit and lending facilities can be found at http://www.federalreserve.gov/newsevents/reform.htm.

${ }^{11}$ It is common knowledge within the financial industry that there is a risk to discount window borrowing in times of financial stress. Borrowing at the discount window during such a time is frequently interpreted as a position of weakness.

${ }^{12}$ See Bernanke (2010).
} 
window, requesting a specified amount of funds and receiving those funds at a rate set by the Fed, banks borrowed in groups through an auction process where they not only set the amount they wished to borrow but also set the rate they were willing to pay (Thornton 2008). Although the Fed set a minimum bid rate, the loans were made at the lowest rate that would deplete the total amount of funds that were to be auctioned that day. The funds were allocated beginning with the highest interest rate offered until either all funds were allocated or all bids were satisfied. All borrowing institutions paid the same interest rate-either the rate associated with the bid that would fully subscribe the auction, or in the case that the total bids were less than the amount of funds offered, the lowest rate that was bid.

The TAF was designed to support depository banks and would run a little over two years, from December 2007 to March 2010 with more than 4000 individual transactions. Over this extended period of time, the mean interest rate on all borrowing from the Fed under this facility was 1.27 percent. Although the first auction in December 2007 had a rate of 4.65 percent, it would precipitously begin to fall, spiking only with the collapse of Lehman Brothers, then tumbling to .25 percent in January 2009 . It would stay at this level for just over a year. See Figure 1.

Figure $1 \mathrm{TAF}$-Weekly average interest rates

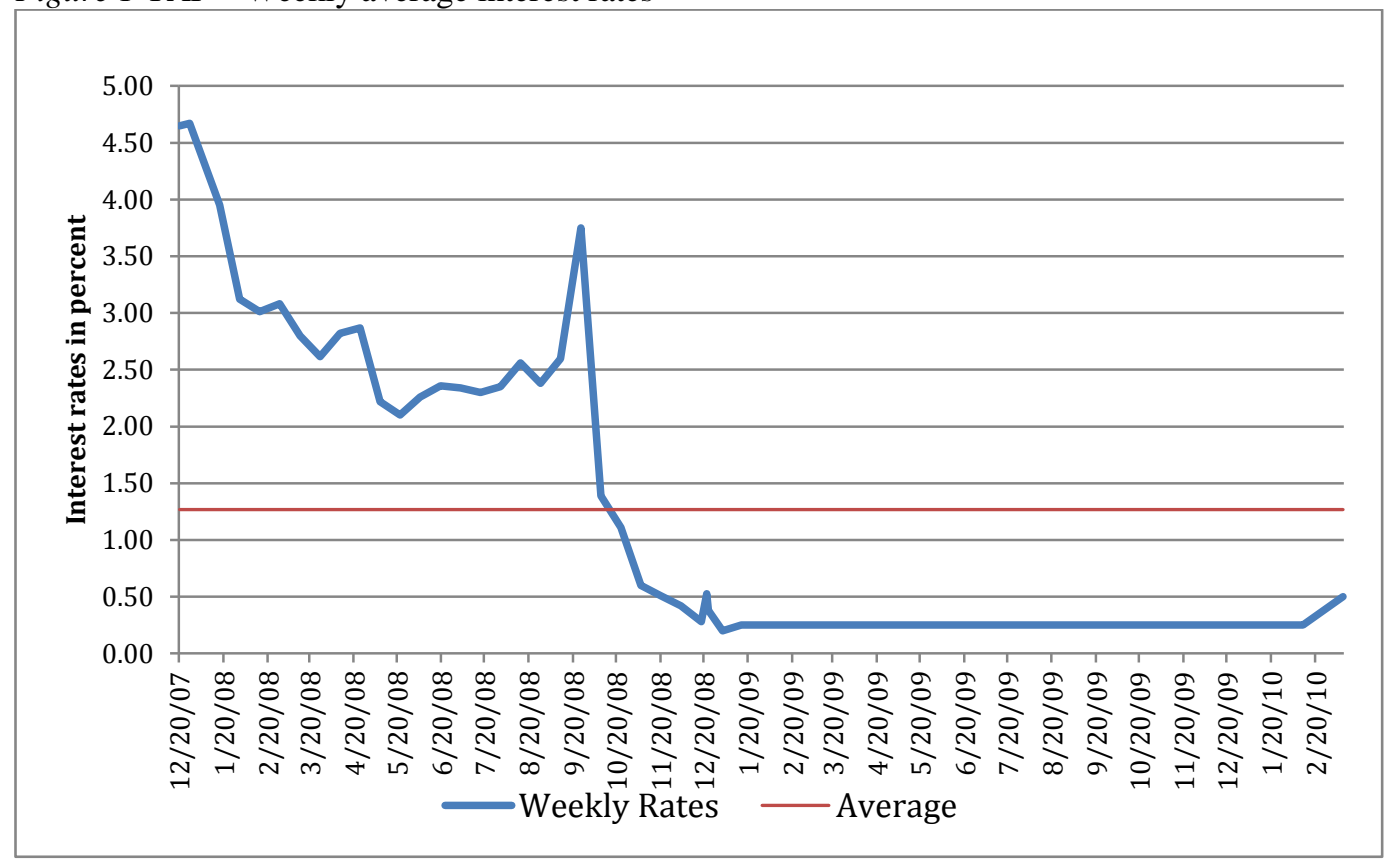

Source: Federal Reserve Board 
A total of 416 unique commercial banks participated in this facility; however, many of these were subsidiaries of larger parent banks. The top ten borrowers in terms of total cumulative borrowing, including their subsidiaries, borrowed collectively at a mean rate of 1.48 percent throughout the facilities duration. The top three cumulative borrowers, Bank of America, Barclays and Royal Bank of Scotland, borrowed $\$ 704.2$ billion dollars at a combined average rate of .78 percent.

Table 1 TAF_-Top 3 borrowers

\begin{tabular}{llrr}
\hline Depository Institution & \multicolumn{2}{c}{$\begin{array}{l}\text { Cumulative Borrowing } \\
\text { in billions }\end{array}$} & $\begin{array}{l}\text { Average } \\
\text { Rates in } \\
\text { percent }\end{array}$ \\
\hline Bank of America & $\$ 260.167$ & 0.4510 \\
Barclays & $\$ 232.283$ & 0.6303 \\
Royal Bank of Scotland & $\$ 211.747$ & 1.2491 \\
\hline \multicolumn{2}{r}{ Total and combined rate } & $\$ 704.197$ & 0.7768 \\
\hline
\end{tabular}

Source: Federal Reserve Board

The lowest borrowing rate came on January 2, 2009 at .2 percent. Seventy-four unique banks would borrow a cumulative total of $\$ 102.979$ billion at this rate. Union Bank NA (which is a subsidiary of Mitsubishi UFJ Financial Group — a Japanese firm) would have the lowest average borrowing rate, borrowing $\$ 4$ million at .238 percent.

\subsection{ST OMO}

The Single-Tranche Open Market Operations (ST OMO) was implemented shortly after the TAF as a temporary measure to address the continuing risks within the financial markets, specifically the repurchase agreement market or repo and was designed to support primary dealers. ${ }^{13}$ The Fed engaged in a series of term repurchasing transactions that spanned from March 2008 to December 2008, approximately nine months with a total of 375 transactions. Along with the TSLF, these operations would contain some of the lowest interest rates for

\footnotetext{
${ }^{13}$ A repurchase agreement or repo is a sale of securities with an agreement to repurchase them at a fixed price at a later date. Investment banks rely heavily upon this market for short-term funding. Although the Fed regularly engages in repurchase agreements, the ST OMO is included here because it was explicitly undertaken to address the liquidity shortfall of the primary dealers, see Bernanke (2008). 
individual banks in the course of the Fed's response to the crisis. However, the overall mean would be higher than the TAF at 1.93 percent, as shown in Figure 2.

Figure 2 ST OMO-Weekly average interest rates

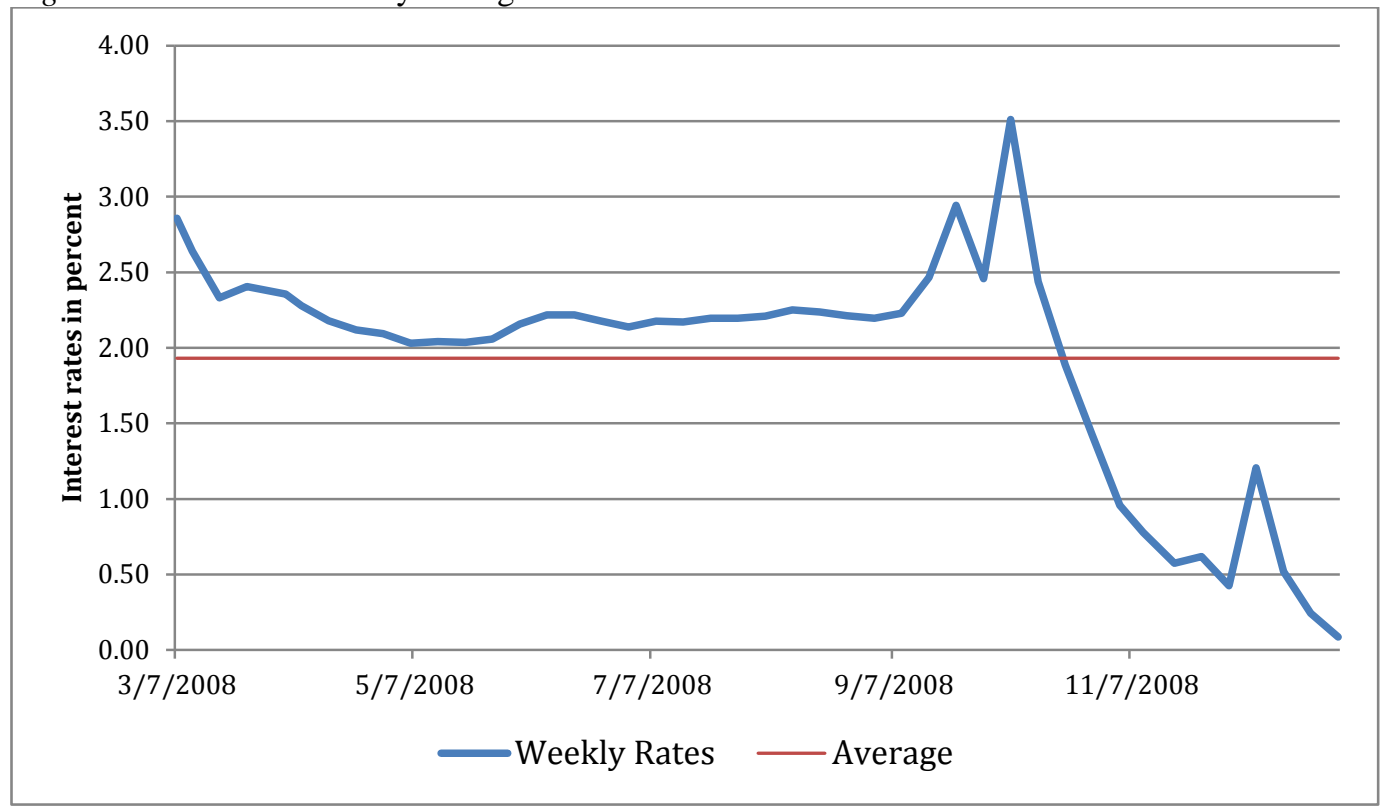

Source: Federal Reserve Board

Nineteen primary dealers participated in the ST OMO. The top eight borrowers, comprising 87 percent of the cumulative total with $\$ 745$ billion, would have a slightly lower borrowing rate from the total average with 1.8 percent. After reaching a peak in October at 3.51 percent, the rates began to decrease dramatically, with two investment banks, Morgan Stanley and Goldman Sachs, receiving a rate as low as .01 percent in December 2008 for $\$ 50$ million and \$200 million, respectively. The top three cumulative borrowers, Credit Suisse, Deutsche Bank, and BNP Paribas, would borrow roughly $\$ 457$ billion at a combined average rate of 1.8 percent. See Table 2 .

Table 2 ST OMO-Top 3 borrowers

\begin{tabular}{l|rr}
\hline Primary Dealer & $\begin{array}{l}\text { Cumulative } \\
\text { Borrowing in billions }\end{array}$ & $\begin{array}{l}\text { Average Rate } \\
\text { in percent }\end{array}$ \\
\hline Credit Suisse & $\$ 259.313$ & 1.825 \\
Deutsche Bank & $\$ 101.031$ & 2.158 \\
BNP Paribas & $\$ 96.549$ & 1.806 \\
\multicolumn{1}{r}{$\quad$ Total \& combined rate } & $\$ 456.893$ & 1.795 \\
\hline
\end{tabular}

Source: Federal Reserve Board 
Overall, Daiwa would have the lowest rate, borrowing $\$ 2.72$ billion at .68 percent, followed closely by JP Morgan, borrowing \$2.5 billion at .75 percent.

\subsection{TSLF}

As the crisis continued, the Fed looked to create a more permanent facility that could support investment banks. After the collapse of Bear Stearns in March 2008, the repo market came under considerable stress. The creation of the Term Securities Lending Facility (TSLF) was directed to remedy this by providing high quality collateral to investment banks. The facility, which loaned US Treasuries through auctions, ran from March 2008 to February 2010, or almost two years, and had 563 individual transactions. ${ }^{14}$ The determination of the interest rates was established by using a single-price auction arrangement. Those bids that were successful were issued loans at the same interest rate. Primary dealers made their bids equivalent to the difference between the rate on lending in the repo market with the then risky securities used as collateral and the rate on lending with safe Treasury securities as collateral (GAO 2011, 241).

The Federal Reserve Board of New York (FRBNY), which implemented the program, created a stop-out rate for each auction by ordering bids from the highest to the lowest, where the acceptance of bids began with the highest rates, "until the total auction amount was allocated or the minimum bid rate for the auction was reached, whichever occurred first; [hence] the interest rate of the lowest successful bid was the rate applied to all other successful bids for that auction" (Ibid., 241). In effect, the bids by primary dealers were representative of the rates that they were willing to pay the Fed to borrow a basket of Treasuries against other forms of collateral that they were holding. Over the course of its operations, the TSLF had a mean interest rate of .38 percent, peaking in October at 3.22 percent (Figure 3).

It must be underscored, however, that a distinction exists between the TSLF and the two other operations mentioned thus far (TAF and ST OMO)—namely that these loans were loans of Treasuries and not cash. Once the primary dealers secured the safe and high quality Treasuries from the Fed, they then turned around and used them as collateral to borrow cash in the repo market. Consequently, primary dealers were paying interest twice to maintain funding flows.

\footnotetext{
${ }^{14}$ The two forms of auctions, Schedule 1 and Schedule 2 are both included in this estimate. The Schedules were differentiated by the types of collateral the Fed would accept. The forms of collateral accepted in Schedule 1 were: Treasury securities, agency securities and agency mortgage-backed securities. Schedule 2 accepted all of Schedule 1 's collateral but also accepted high rated securities, such as asset-backed securities and investment grade securities.
} 
Figure 3 TSLF-Weekly average interest rates

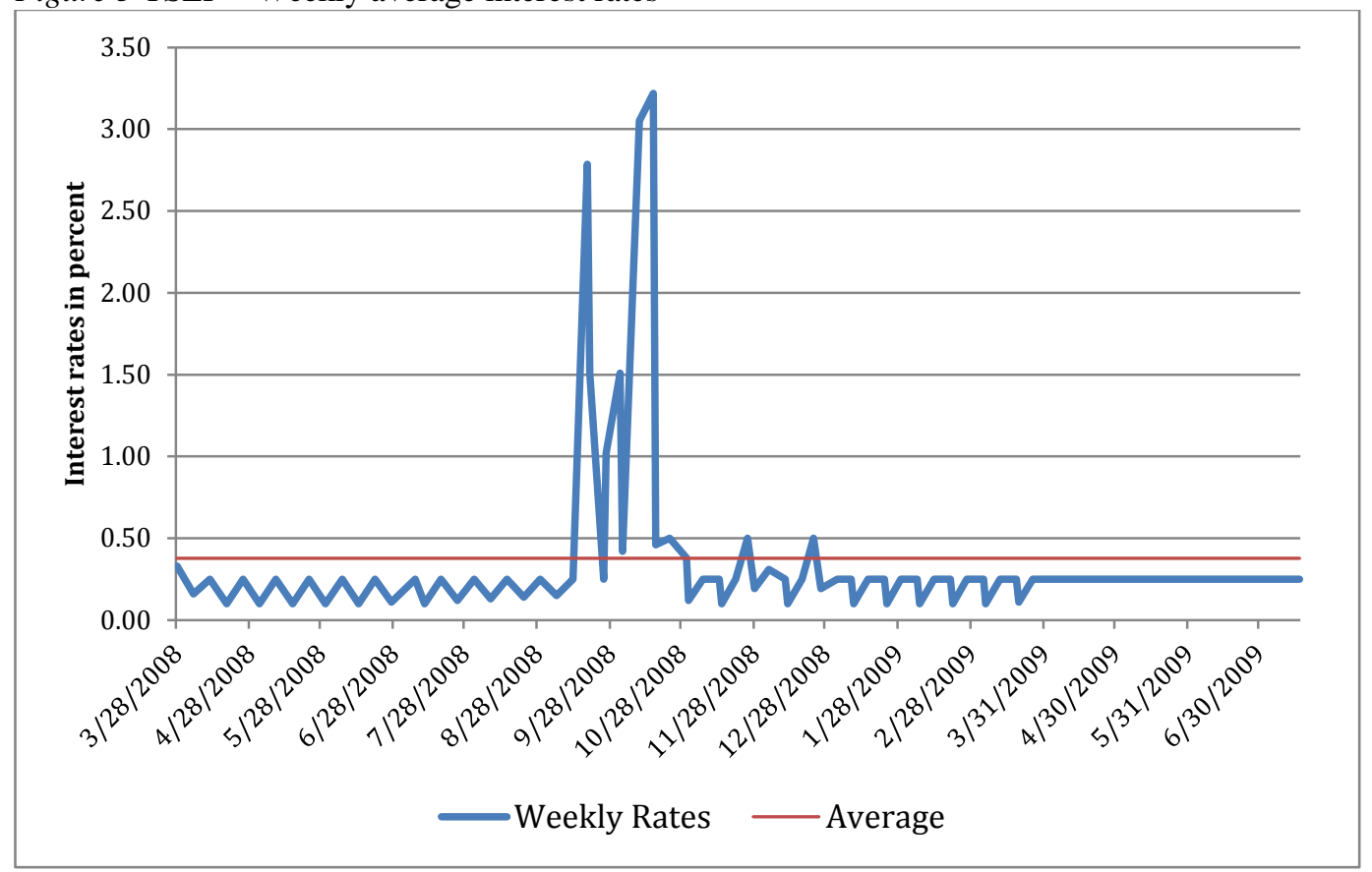

Source: Federal Reserve Board

Access to the TSLF was limited to eighteen primary dealers. Nine of these would comprise 86 percent of the overall cumulative borrowing that totaled $\$ 1.7$ trillion dollars with a mean interest rate of .48 percent. The top three largest cumulative borrowers, Citigroup, Credit Suisse, and Deutsche Bank, would borrow roughly $\$ 761$ billion at a combined average rate of .42 percent. The lowest mean borrowing rate for a primary dealer, overall, was Dresdner, borrowing $\$ 1.1$ billion at a mean rate of .10 percent.

Table 3 TSLF-Top 3 borrowers

\begin{tabular}{|c|c|c|}
\hline Primary Dealer & $\begin{array}{l}\text { Cumulative borrowing in } \\
\text { billions }\end{array}$ & $\begin{array}{l}\text { Average rate } \\
\text { in percent }\end{array}$ \\
\hline Citigroup & $\$ 297.297$ & 0.32 \\
\hline Credit Suisse & $\$ 224.535$ & 0.52 \\
\hline Deutsche Bank & $\$ 239.248$ & 0.43 \\
\hline Total and combined average & $\$ 761.080$ & 0.42 \\
\hline
\end{tabular}

Source: Federal Reserve Board

The Primary Dealer Credit Facility (PDCF), as distinct from the TSLF, provided liquidity to investments banks by loaning cash in exchange for collateral instead of Treasury securities. Running from March 2008 to April 2009, or just over one year, it would have a mean 
interest rate over its duration of 1.39 percent. In December 2008, the rate would drop to .50 percent and stay at this level until it ceased operations. This facility would have a total of 1,381 individual transactions.

Figure 4 PDCF-Weekly average interest rates

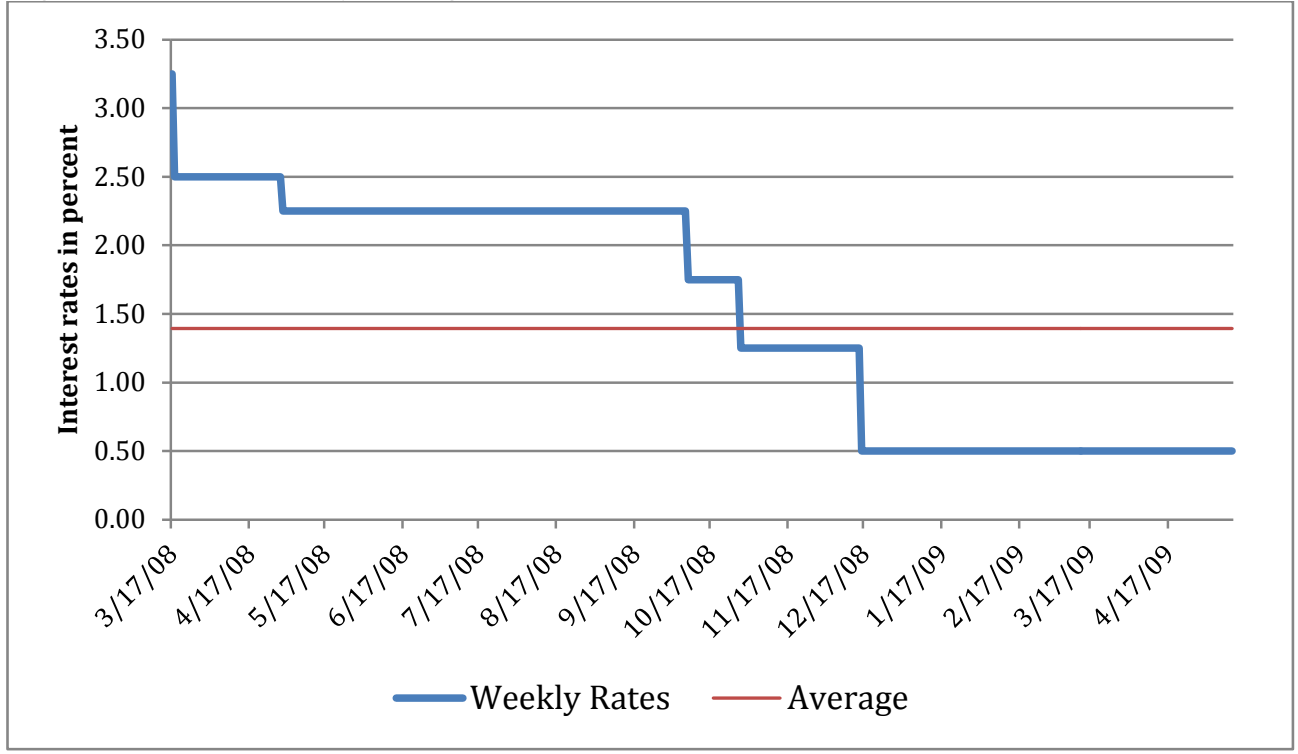

Source: Federal Reserve Board

As with the TSLF, the PDCF was limited to 18 primary dealers. The largest three cumulative borrowers, Citigroup, Merrill Lynch, and Morgan Stanley, would borrow just over $\$ 6$ trillion with a combined mean interest rate of 1.065 percent. ${ }^{15}$ Citigroup would have the lowest overall mean borrowing rate amongst the primary dealers with .885 percent.

Table 4 PDCF-Top 3 borrowers

\begin{tabular}{lrr}
\hline Primary Dealer & Cumulative borrowing in billions & $\begin{array}{l}\text { Average rate } \\
\text { in percent }\end{array}$ \\
\hline Citigroup & $\$ 2,020.219$ & 0.885 \\
Merrill & $\$ 2,081.389$ & 1.120 \\
Morgan Stanley & $\$ 1,912.625$ & 1.190 \\
\hline Total and combined average & $\$ 6,014.233$ & 1.065 \\
\hline
\end{tabular}

Source: Federal Reserve Board

\footnotetext{
${ }^{15}$ These totals and rates of the primary dealers include their London subsidiaries.
} 


\section{BEAR STEARNS-MAIDEN LANE I; AIG-RCF, SBF, AND MAIDEN LANE II \& III: DIRECT SUPPORT TO INDIVIDUAL INVESTMENT AND INSURANCE INSTITUTIONS}

\subsection{Bear Stearns}

During the crisis, Bear Stearns, an investment bank, and American International Group (AIG), an insurance corporation, received direct assistance from the Fed. Three special purpose vehicles (SPVs), Maiden Lane I, II, and III LLC, were created to facilitate this process. ${ }^{16}$ By mid-March 2008, Bear Stearns was facing possible bankruptcy; if it were to survive, it would need either heavy injections of liquidity by the Fed or an acquisition by a stronger investment firm. As it turns out, it would receive both. The negotiations that followed merged Bear and JP Morgan and produced Maiden Lane I - an SPV with a loan from the FRBNY totaling \$28.82 billion. The implementation of this loan took place toward the end of June 2008 and had a 10year renewable term. The interest rate was set at the primary rate (Figure 5) with an average of .81 percent. After approximately four years and six months, the loan was repaid in full with interest on June 14, 2012.

Figure 5 Bear Stearns, Maiden Lane I

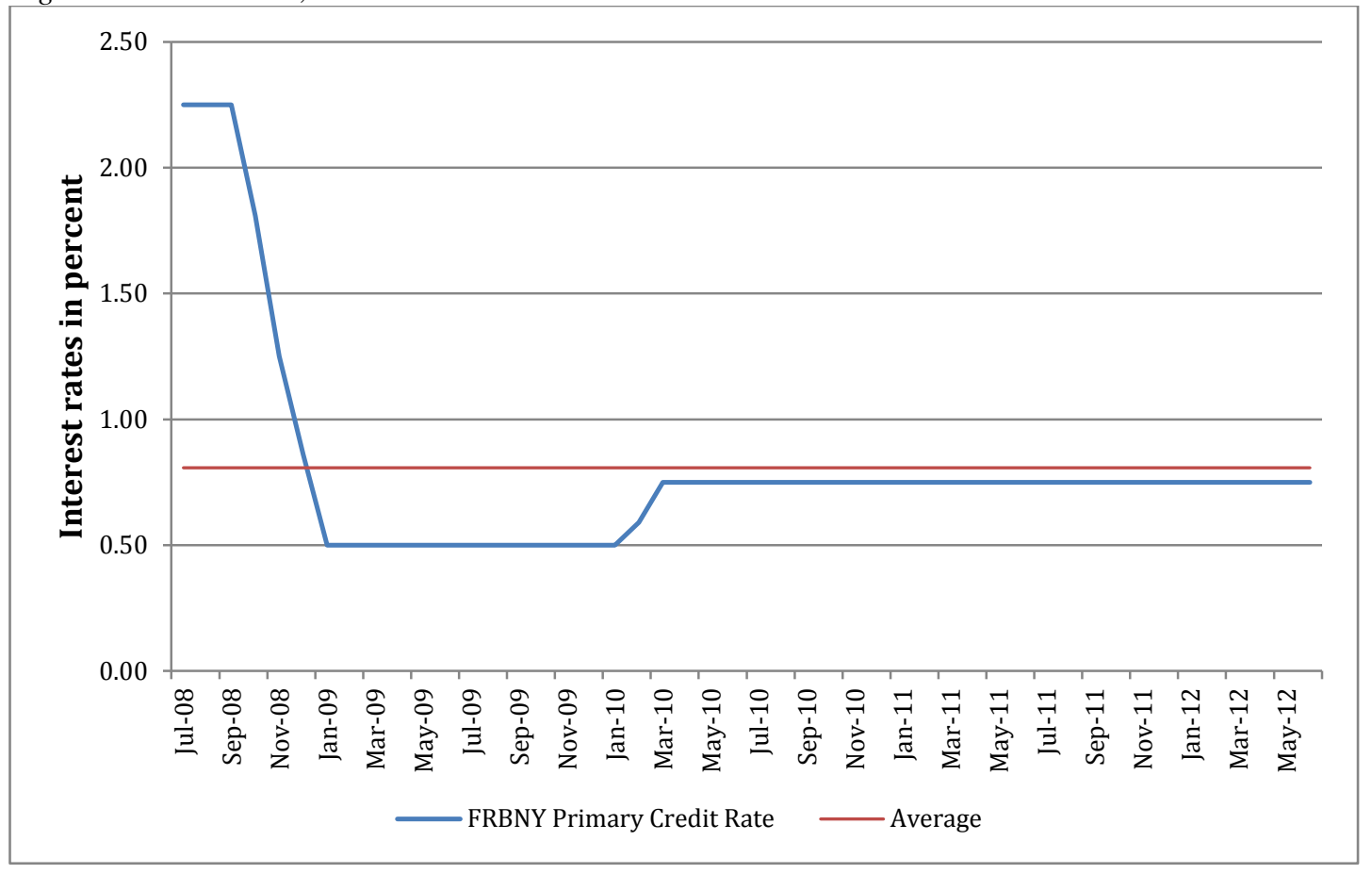

Source: Federal Reserve Board

\footnotetext{
${ }^{16}$ An SPV is a legal entity such as a limited partnership. One advantage that it has is to remove illiquid assets off balance sheets and out of the market.
} 


\subsection{AIG}

Approximately six months following Bear's collapse and on the heels of the Lehman bankruptcy, AIG would also come under considerable stress. Yet AIG would require substantially more assistance than Bear and hence the FRBNY created a total of four programs in its effort to rescue it. The first among them was the Revolving Credit Facility (RFC) announced on September 16, 2008. The interest rate was originally set at one-month LIBOR plus 850 bps. ${ }^{17}$ In addition to this, a minimum floor of LIBOR plus 350 bps was set. In November 2008, the rates were lowered to one-month LIBOR plus 300 bps and the floor was removed entirely in April 2009 (GAO 2011, 167-8). The RCF was initially authorized for up to two years and was extended in November 2008 to five years. Its average rate over its duration was 4.95 percent. The following month (October), the Securities Borrowing Facility (SBF) was created to lend up to $\$ 37.8$ billion to AIG insurance subsidiaries (largely AIG's life insurance companies) at any one time. The interest rates on these loans were set at $100 \mathrm{bps}$ plus the average overnight repurchase agreement rate offered by dealers for the pertinent collateral type. ${ }^{18}$ The loans were overnight with the option of rolling them and originally authorized up to September 16, 2010. Yet the SBF lasted approximately only two months having an average rate of 2.36 percent. Despite the relatively short time span, AIG drew on this facility 44 times.

An SPV, Maiden Lane II, established in November 2008, would replace the SBF and serve as a longer-term solution for AIG's liquidity problems. AIG was able to repay its obligations on the SBF and terminate this program by using the proceeds from the FRBNY loan, totaling \$19.5 billion, in exchange for residential mortgage-backed securities (RMBSs). The interest rate for this loan was fixed at one-month LIBOR plus $100 \mathrm{bps}$. The term to maturity for this loan was six years with the option to extend. As of March 2012, this loan has been repaid in full; its average rate over the duration was 1.34 percent.

Another SPV, Maiden Lane III, also announced in November, was created to restructure the financial support to AIG by purchasing collateralized debt obligations (CDOs). FRBNY provided a $\$ 24.3$ billion loan while AIG was required to contribute $\$ 5$ billion in equity to the

\footnotetext{
${ }^{17}$ It is striking to note that the Fed chose to set several of its loans to LIBOR knowing that this rate was being fixed. The typical explanation for using market rates, economic efficiency, clearly cannot be justified in this case. The fact that the Fed knowingly used a rate that was artificially suppressed raises questions about its intent and its association to many of these large banks. For more information, see FRBNY (2012).

${ }^{18}$ The Fed did not release the exact rate for these loans but instead provided a minimum and maximum range. An approximate calculation for the mean interest rates for the SBF was attained by taking the median for each individual loan followed by the average of these for the month.
} 
SPV. The interest rate on the FRBNY loan is one-month LIBOR plus $100 \mathrm{bps}$. Its average rate was 1.29 percent. The term to maturity on the FRBNY loan was also set at six years with the option to extend. The outstanding principal amount on Maiden Lane III was repaid in full with interest on June 14, 2012.

Figure 6 AIG-RCF, SBF, Maiden Lane II \& III

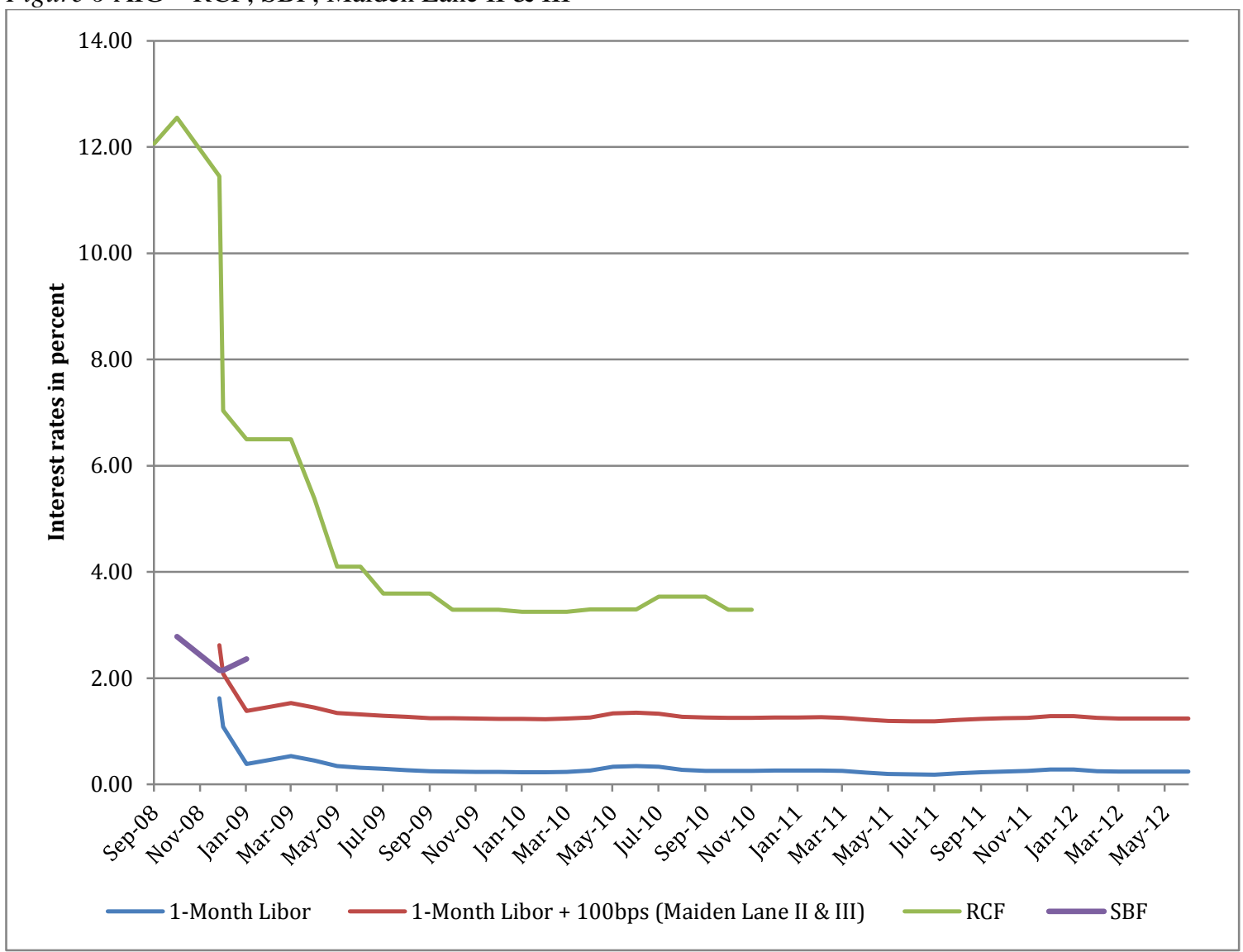

Source: Federal Reserve Board and the Wall Street Journal

\section{AMLF, CPFF, AND TALF: SUPPORT TO CREDIT MARKETS}

\subsection{AMLF}

The creation of the Asset-Backed Commercial Paper Money Market Mutual Fund Liquidity Facility (AMLF) was the first of all the facilities to be directed at credit markets. It was specifically designed to support money market mutual funds (MMMFs) that had come under considerable stress and were facing increased redemption pressures after Lehman Brothers filed for bankruptcy on September 14, 2008. The facility made nonrecourse loans to intermediary 
borrowers to purchase asset-backed commercial paper (ABCP) from the MMMFs. This indirect process was the result of limitations on the Fed to fund MMMFs directly, making necessary the use of intermediary financial institutions. The AMLF's primary intention was to assist MMMFs holding ABCP to meet their redemption demands as well as to provide liquidity in both the ABCP and the broader money markets (Federal Reserve 2009).

The AMLF ran from September 2008 to February 2010 or close to one and a half years with 1,135 transactions. The loans were dispensed through the Federal Reserve Bank of Boston (FRBB) with the same rate for all borrowers set equal to the primary credit rate of the FRBB, with the average mean rate of .77 percent; see Figure 7. Though the initial lending rate was 2.25 percent, as with many other facilities, it would drop in December and then again in January, settling at .50 percent for the remaining duration of the facility. The term to maturity could not exceed 120 days for depository institutions and 270 days for all other eligible borrowers.

Figure 7 AMLF-Monthly average interest rates

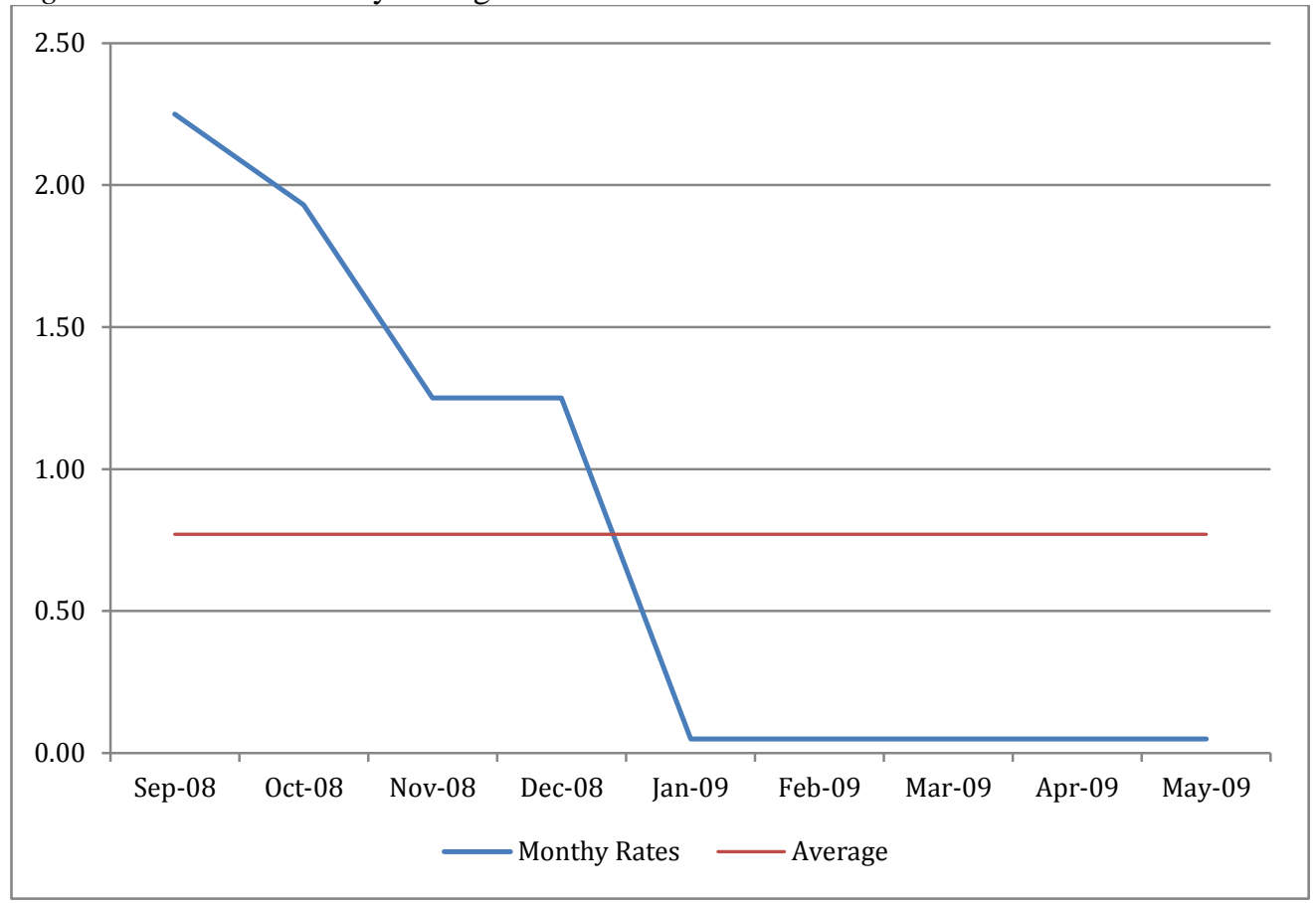

Source: Federal Reserve Board

There would be only seven parent banks that participated in the AMLF. Most of the borrowing took place in September 2008, totaling $\$ 159$ billion or 73 percent of all borrowing; thus, each bank would carry a higher rate than the average (.77 percent) over the course of the 
facility. ${ }^{19}$ JP Morgan and State Street would comprise the bulk of the borrowing (92 percent) with a combined mean rate of 2.07 percent. Credit Suisse, followed closely by Citigroup, would have the lowest rates overall with 1.75 percent and 1.76 percent, respectively; see Table 5 . Three out of the seven banks would borrow at the lowest rate (.05 percent) —Citigroup, JP Morgan, and State Street. JP Morgan would borrow from the FRBB 144 times at this rate, while State Street borrowed 35 times and Citigroup 11.

Table 5 AMLF-All borrowers

\begin{tabular}{|c|c|c|}
\hline Institution & $\begin{array}{l}\text { Cumulative } \\
\text { borrowing in } \\
\text { billions }\end{array}$ & $\begin{array}{l}\text { Average rate } \\
\text { in percent }\end{array}$ \\
\hline JP Morgan Chase & $\$ 111.413$ & 1.987 \\
\hline State Street Corp. & $\$ 89.241$ & 2.151 \\
\hline Bank of NY Mellon & $\$ 12.924$ & 2.245 \\
\hline Bank of America Corp. & $\$ 1.557$ & 2.118 \\
\hline Citigroup & $\$ 1.436$ & 1.763 \\
\hline Suntrust & $\$ 0.540$ & 2.179 \\
\hline Credit Suisse & $\$ 0.238$ & 1.750 \\
\hline Total and combined average & $\$ 217.349$ & 2.028 \\
\hline
\end{tabular}

Source: Federal Reserve Board

\subsection{CPFF}

Like AMLF, the Commercial Paper Funding Facility (CPFF) was also directed toward credit markets and had nearly the same operational duration, running from October 2008 to February 2010 with 1,159 transactions. Unlike AMLF, this facility was designed to support the commercial paper (CP) market rather than MMMFs. Because the $\mathrm{CP}$ market saw its funding move into safer securities after Lehman's collapse - primarily government treasuries_-issuers faced rollover risk and a plummeting issuance rate ${ }^{20}$ The $\mathrm{CP}$ market would shrink by as much as $\$ 300$ billion by the end of October 2008 (a month after Lehman's bankruptcy) with 70 percent of this due to reductions in the issuance of financial $\mathrm{CP}$ and 20 percent from $\mathrm{ABCP}$

\footnotetext{
${ }^{19}$ Over its duration, the AMLF had an average rate of .77 percent; this includes the last five months in which it had a rate of .50 percent. However, the majority of all the borrowing, which came in the first month, had a much higher rate-2.25 percent. Therefore, each individual's average was higher than the average duration of the facility.

${ }^{20}$ Rollover risk is the risk issuers face when investors no longer desire to rollover the CP.
} 
(Adrian, Kimbrough, Marchioni 2011). A new source of funding was required to drive new issuances of $\mathrm{CP}$. Because purchasing $\mathrm{CP}$ by issuers was outside the operating framework of the Fed, the creation of an SPV to buy $\mathrm{CP}$ was a necessary step. Providing funding to issuers of $\mathrm{CP}$ not only drove new issuances and decreased the interest rate issuers would have to pay to borrow funds but it also decreased the level of asset sales by those that found themselves unable to raise cash and decreased the pressure on credit lines by commercial banks, thus increasing credit availability.

There were a total of 120 unique participants in this facility, but as with the TAF, many of these were subsidiaries of larger parent banks. The commercial paper issued was 3-month US dollar denominated debt and the rates were set at a fixed spread above the daily 3-month overnight indexed swap (OIS) rate. Essentially, the Fed lent against specific collateral types with asset-backed commercial paper having the highest lending costs due to higher risk and illiquidity (Ibid.). A credit surcharge was imposed for unsecured paper. The pricing structure is illustrated in Table 6.

Table $6 \mathrm{CPFF}$

\begin{tabular}{lll} 
Rates and Fees & Unsecured Commercial Paper & $\begin{array}{l}\text { Asset-Backed Commercial } \\
\text { Paper }\end{array}$ \\
\hline Lending rate & $\begin{array}{l}\text { Three-month OIS }+100 \\
\text { basis points }\end{array}$ & $\begin{array}{l}\text { Three-month OIS }+300 \\
\text { basis points }\end{array}$ \\
Credit surcharge & 100 basis points & $\begin{array}{l}\text { None } \\
\text { All-in cost }\end{array}$ \\
$\begin{array}{l}\text { Three-month OIS }+200 \\
\text { basis points }\end{array}$ & $\begin{array}{l}\text { Three-month OIS }+300 \\
\text { basis points }\end{array}$ \\
\hline
\end{tabular}

Source: CPFF Terms and Conditions, FRBNY.

Throughout CPFF's duration, it would have a mean interest rate of 2.89 percent (Figure 8). As Table 7 illustrates, the top three cumulative borrowers of the CPFF were UBS, AIG, and Dexia. They would have mean interest rates of 2.45 percent, 2.62 percent, and 2.37 percent, respectively. Bank of America would have the lowest mean rate, overall, with 1.82 percent. The lowest rate was offered to Citigroup on January 15, 2009 at 1.16 percent. 
Figure $8 \mathrm{CPFF}$-Average daily interest rates

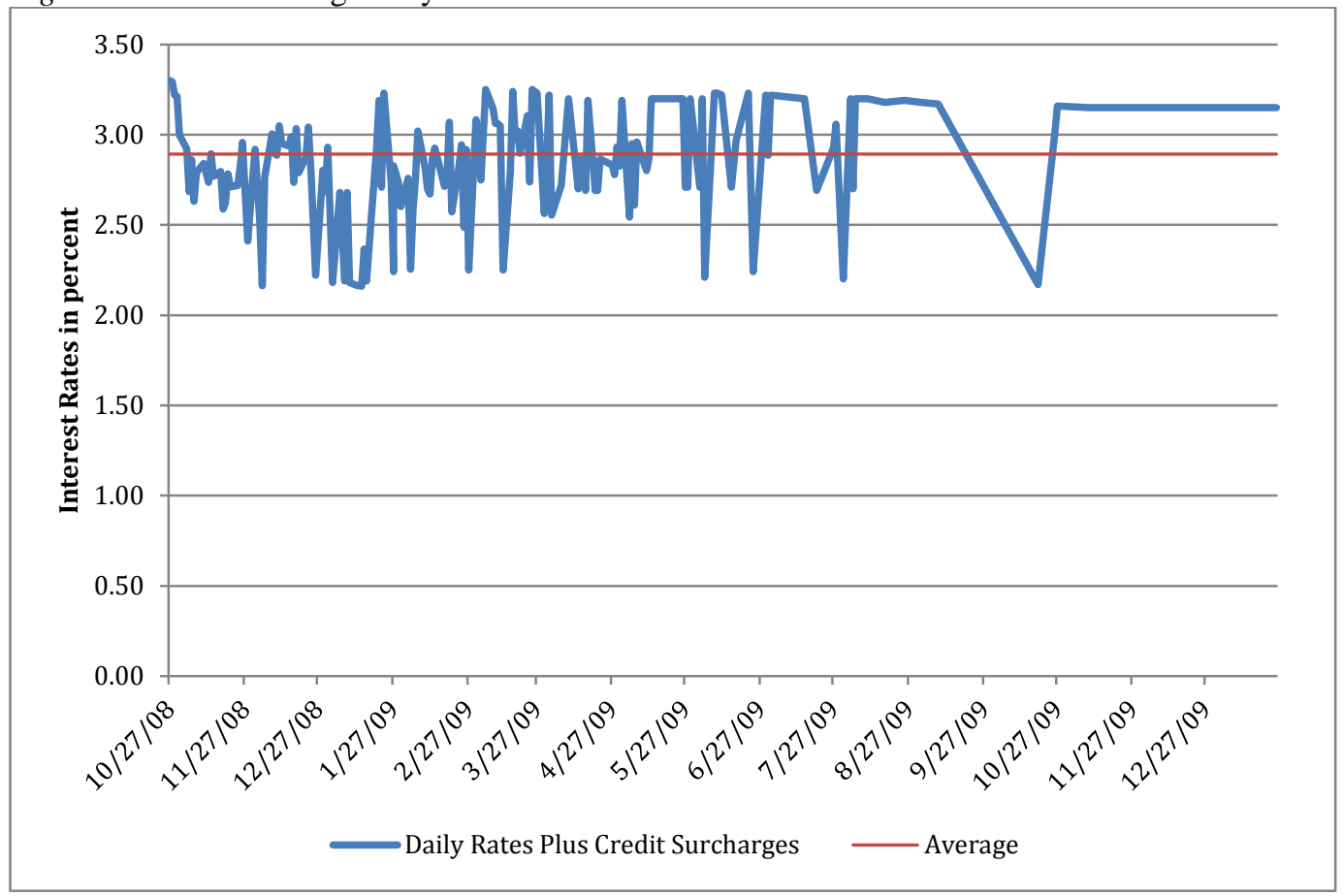

Source: Federal Reserve Board

Table 7 CPFF-Top 3 borrowers

\begin{tabular}{|c|c|c|}
\hline Institution & $\begin{array}{l}\text { Cumulative borrowing in } \\
\text { billions }\end{array}$ & $\begin{array}{l}\text { Average rate + } \\
\text { surcharge, in } \\
\text { percent }\end{array}$ \\
\hline UBS & $\$ 74.531$ & 2.45 \\
\hline AIG & $\$ 60.231$ & 2.62 \\
\hline DEXIA & $\$ 53.476$ & 2.37 \\
\hline Total and combined average & $\$ 188.238$ & 2.48 \\
\hline
\end{tabular}

Source: Federal Reserve Board

\subsection{TALF}

Despite the arsenal of facilities created by the Fed, including the newly established programs directed at the credit markets, turmoil persisted. Much of the problem that remained was due to longer-term assets, such as asset-backed securities (ABSs) that securitized student loans, small business loans, credit cards, equipment, and commercial mortgages. But even more importantly, there was still a substantial and extensive problem with asset-backed securities in the mortgage 
market. The Term Asset-Backed Securities Loan Facility (TALF) was created to increase credit availability to ABSs while the Agency Mortgage-Backed Securities Program (MBS) was designed to ease pressures in the mortgage market by also increasing the availability of credit and reducing its cost. These two programs were announced in tandem on November 25, 2008. Although the outright purchases of mortgage-backed securities were the fundamental components in ending the panic, they will not be addressed here, as has already been discussed above.

The TALF would run from March 2009 to June 2010 or roughly a little over a year and have over 2,000 transactions. The intention of the TALF was to drive new issues of ABSs in order to increase the flow of credit to households and small businesses. The Fed issued nonrecourse loans up to five years to holders of eligible ABSs and lending rates took two forms: fixed and floating plus a margin. ${ }^{21}$ The last fixed rate loan took place at the end of March 2010. Like the CPFF, the TALF had a multiple pricing structure. The rates were set according to particular types of collateral, as shown in Table 8 below.

\begin{tabular}{|c|c|c|c|c|c|c|}
\hline \multirow[t]{2}{*}{ Sector } & Subsector & \multicolumn{3}{|c|}{$\begin{array}{l}\text { Fixed } 3 \text { year loan (Average Life, in } \\
\text { years) }\end{array}$} & \multirow[t]{2}{*}{$\begin{array}{l}\text { Fixed } 5 \\
\text { year } \\
\text { loan }\end{array}$} & \multirow[t]{2}{*}{ Floating } \\
\hline & & $<1$ & $1-<2$ & $>=2$ & & \\
\hline Auto & & $\begin{array}{l}\text { 1-year } \\
\text { LIBOR } \\
\text { swap } \\
\text { rate }\end{array}$ & $\begin{array}{l}2 \text {-year } \\
\text { LIBOR } \\
\text { swap rate } \\
+100 \text { bps }\end{array}$ & $\begin{array}{l}\text { 3-year } \\
\text { LIBOR } \\
\text { swap } \\
\text { rate }\end{array}$ & N/A & $\begin{array}{l}1-\text { month } \\
\text { LIBOR + } \\
100 \text { bps }\end{array}$ \\
\hline $\begin{array}{l}\text { Commercial } \\
\text { mortgage }\end{array}$ & & & $\begin{array}{c}\text { 3-year } \\
\text { LIBOR } \\
\text { swap rate } \\
+100 \text { bps }\end{array}$ & & $\begin{array}{l}\text { 5-year } \\
\text { LIBOR } \\
\text { swap } \\
\text { rate }+ \\
100 \text { bps }\end{array}$ & N/A \\
\hline Credit Card & & $\begin{array}{l}\text { 1-year } \\
\text { LIBOR } \\
\text { swap } \\
\text { rate }+ \\
100 \text { bps }\end{array}$ & $\begin{array}{l}2 \text {-year } \\
\text { LIBOR } \\
\text { swap rate } \\
+100 \text { bps }\end{array}$ & $\begin{array}{l}\text { 3-year } \\
\text { LIBOR } \\
\text { swap } \\
\text { rate }+ \\
100 \text { bps }\end{array}$ & N/A & $\begin{array}{l}\text { 1-month } \\
\text { LIBOR + } \\
100 \text { bps }\end{array}$ \\
\hline Equipment & & $\begin{array}{l}1 \text {-year } \\
\text { LIBOR } \\
\text { swap } \\
\text { rate }+ \\
100 \text { bps }\end{array}$ & $\begin{array}{l}2 \text {-year } \\
\text { LIBOR } \\
\text { swap rate } \\
+100 \text { bps }\end{array}$ & $\begin{array}{l}\text { 3-year } \\
\text { LIBOR } \\
\text { swap } \\
\text { rate }+ \\
100 \text { bps }\end{array}$ & N/A & $\begin{array}{l}1-\text { month } \\
\text { LIBOR + } \\
100 \text { bps }\end{array}$ \\
\hline Floorplan & & $\begin{array}{l}\text { 1-year } \\
\text { LIBOR } \\
\text { swap }\end{array}$ & $\begin{array}{l}\text { 2-year } \\
\text { LIBOR } \\
\text { swap rate }\end{array}$ & $\begin{array}{l}\text { 3-year } \\
\text { LIBOR } \\
\text { swap }\end{array}$ & N/A & $\begin{array}{l}\text { 1-month } \\
\text { LIBOR + }\end{array}$ \\
\hline
\end{tabular}

\footnotetext{
${ }^{21}$ Nonrecourse loans are loans in which the borrower is not personally liable. The loan is secured with collateral, but in the case of a default, the lender's recovery is restricted to the collateral only.
} 


\begin{tabular}{|c|c|c|c|c|c|c|}
\hline & & $\begin{array}{l}\text { rate }+ \\
100 \text { bps }\end{array}$ & +100 bps & $\begin{array}{l}\text { rate }+ \\
100 \text { bps }\end{array}$ & & 100 bps \\
\hline $\begin{array}{l}\text { Premium } \\
\text { Finance }\end{array}$ & $\begin{array}{l}\text { Property and } \\
\text { casualty }\end{array}$ & $\begin{array}{l}\text { 1-year } \\
\text { LIBOR } \\
\text { swap } \\
\text { rate + } \\
100 \text { bps }\end{array}$ & $\begin{array}{l}\text { 2-year } \\
\text { LIBOR } \\
\text { swap rate } \\
+100 \text { bps }\end{array}$ & $\begin{array}{l}\text { 3-year } \\
\text { LIBOR } \\
\text { swap } \\
\text { rate + } \\
100 \text { bps }\end{array}$ & $\mathrm{N} / \mathrm{A}$ & $\begin{array}{l}1-\text { month } \\
\text { LIBOR + } \\
100 \text { bps }\end{array}$ \\
\hline $\begin{array}{l}\text { Servicing } \\
\text { Advances }\end{array}$ & $\begin{array}{l}\text { Residential } \\
\text { mortgages }\end{array}$ & $\begin{array}{l}\text { 1-year } \\
\text { LIBOR } \\
\text { swap } \\
\text { rate }+ \\
100 \text { bps }\end{array}$ & $\begin{array}{l}2 \text {-year } \\
\text { LIBOR } \\
\text { swap rate } \\
+100 \text { bps }\end{array}$ & $\begin{array}{l}\text { 3-year } \\
\text { LIBOR } \\
\text { swap } \\
\text { rate }+ \\
100 \text { bps }\end{array}$ & $\mathrm{N} / \mathrm{A}$ & \\
\hline $\begin{array}{l}\text { Small } \\
\text { Business }\end{array}$ & $\begin{array}{l}\text { SBA loans } \\
7(a)\end{array}$ & N/A & N/A & N/A & $\mathrm{N} / \mathrm{A}$ & $\begin{array}{l}\text { Fed } \\
\text { Funds } \\
\text { Target + } \\
75 \text { bps }\end{array}$ \\
\hline $\begin{array}{l}\text { Small } \\
\text { Business }\end{array}$ & $\begin{array}{l}\text { SBA loans } \\
504\end{array}$ & \multicolumn{3}{|c|}{ 3-year LIBOR swap rate +50 bps } & $\begin{array}{l}\text { 5-year } \\
\text { LIBOR } \\
\text { swap } \\
\text { rate }+ \\
50 \text { bps }\end{array}$ & N/A \\
\hline $\begin{array}{l}\text { Student } \\
\text { Loan }\end{array}$ & $\begin{array}{l}\text { Private with } \\
\text { coupon tied } \\
\text { to Prime }\end{array}$ & N/A & N/A & N/A & $\mathrm{N} / \mathrm{A}$ & $\begin{array}{l}\text { Higher of } \\
\text { (Prime } \\
\text { rate-175 } \\
\text { bps) and } \\
1 \%\end{array}$ \\
\hline $\begin{array}{l}\text { Student } \\
\text { Loan }\end{array}$ & $\begin{array}{l}\text { Other } \\
\text { Private }\end{array}$ & N/A & N/A & N/A & N/A & $\begin{array}{l}\text { 1-month } \\
\text { LIBOR + } \\
100 \text { bps }\end{array}$ \\
\hline $\begin{array}{l}\text { Student } \\
\text { Loan }\end{array}$ & $\begin{array}{l}\text { Gov't } \\
\text { guaranteed }\end{array}$ & $\mathrm{N} / \mathrm{A}$ & N/A & N/A & N/A & $\begin{array}{l}\text { 1-month } \\
\text { LIBOR + } \\
50 \text { bps }\end{array}$ \\
\hline
\end{tabular}

Source: TALF FAQ, FRBNY

The TALF was not restricted to banks only, but was open to any US company that owned eligible collateral. There would be 177 unique participants, though as with the TAF and the CPFF, many of these were subsidiaries of larger parent institutions. Throughout the TALF's duration, the average fixed rate was 2.91 percent. For the period of March 2009 to December 2012, the average floating rates have been: $1 \mathrm{~m}$ LIBOR $+100 \mathrm{bps}=\mathbf{1 . 2 6}$ percent, FFR +75 bps $=.89$ percent and Prime -1.75 bps $=\mathbf{1 . 5}$ percent; see Figures 9 and 10 . 
Figure 9 TALF-Monthly fixed rates

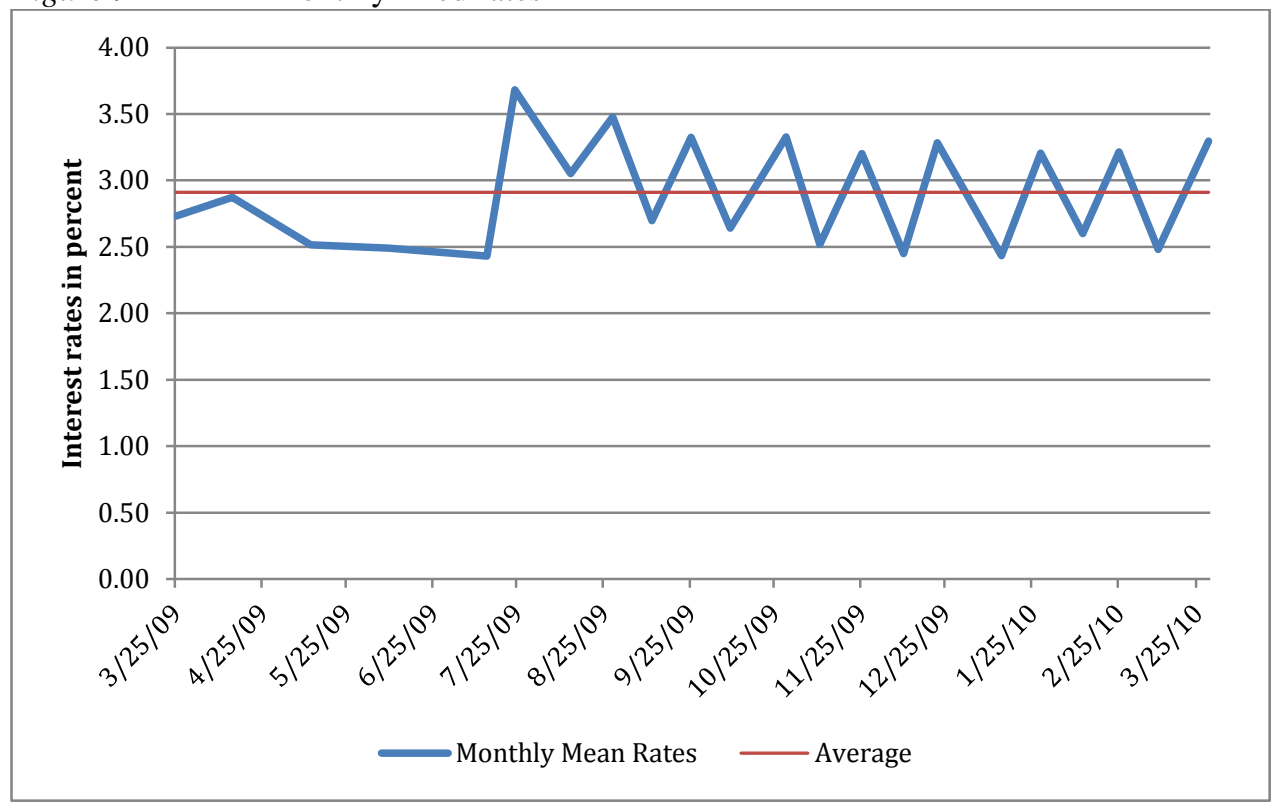

Source: Federal Reserve Board.

Figure $10 \mathrm{TALF}$ - Floating rates plus margin

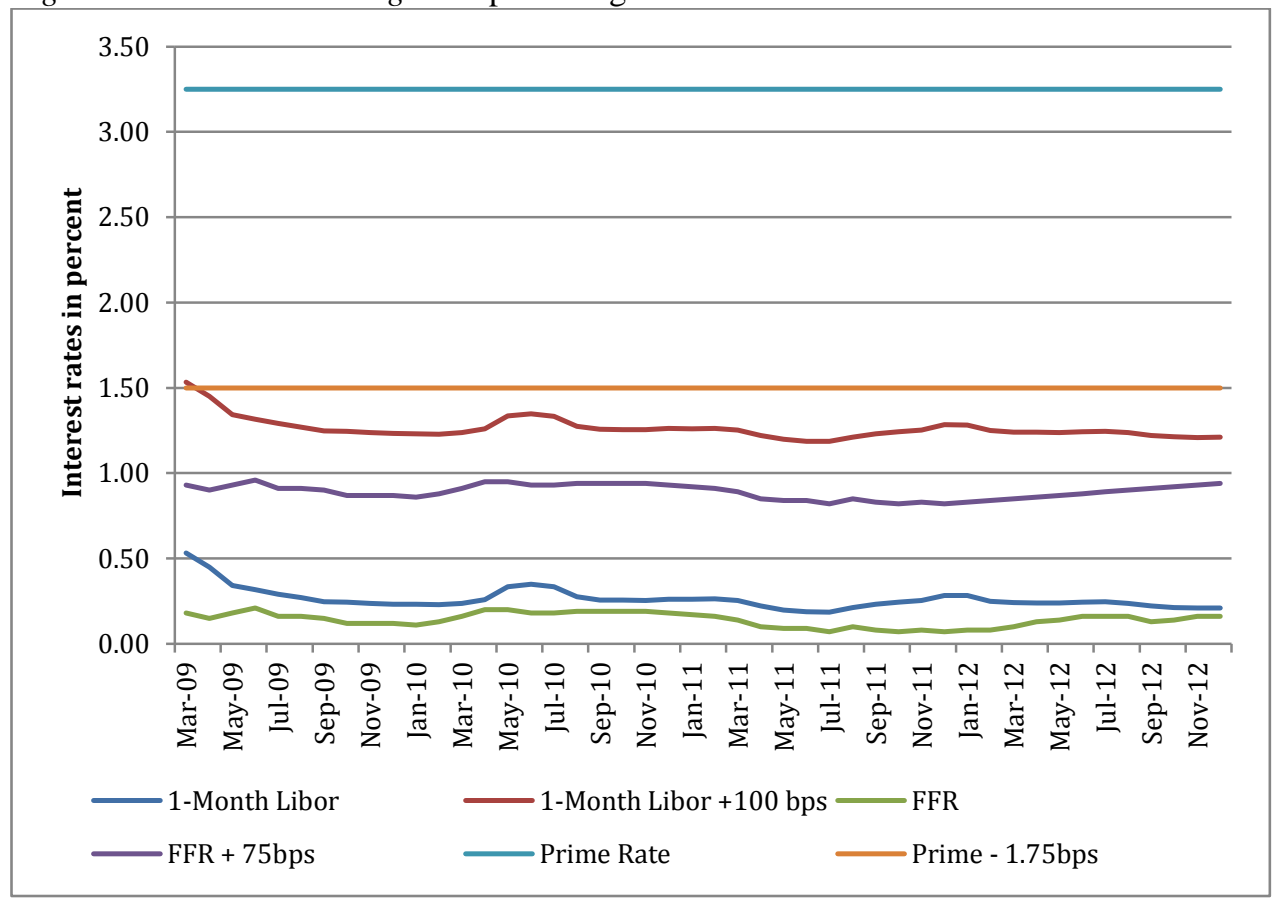

Source: Federal Reserve Board

The top three cumulative borrowers would borrow roughly $\$ 22$ billion or 65 percent of the total borrowing. Together, they would have a weighted average rate of 1.76 percent; see 
Table 9. The lowest fixed rates in the TALF were set at 1.78 percent on July 14, 2009 with nine participants, for a total of $\$ 354$ million. The lowest fixed average rate, overall, for a single borrower was Talisman TALF, LLC, borrowing \$101 million at 2.09 percent.

Table 9 TALF-Top 3 borrowers

\begin{tabular}{|c|c|c|}
\hline Institution & $\begin{array}{l}\text { Cumulative } \\
\text { Borrowing in } \\
\text { billions }\end{array}$ & $\begin{array}{l}\text { Average and } \\
\text { weighted average } \\
\text { rates in percent* }\end{array}$ \\
\hline \multicolumn{3}{|l|}{ Morgan Stanley } \\
\hline Fixed Rates & $\$ 2.961$ & 2.82 \\
\hline \multicolumn{3}{|l|}{ Floating Rates } \\
\hline $1 \mathrm{~m} \mathrm{LIBOR}+100$ bps & $\$ 6.167$ & 1.25 \\
\hline \multirow[t]{2}{*}{ O/N Prime - 175 bps } & $\$ 0.123$ & 1.50 \\
\hline & $\$ 9.251$ & 1.76 \\
\hline \multicolumn{3}{|l|}{ PIMCO } \\
\hline Fixed Rates & $\$ 3.365$ & 3.07 \\
\hline \multicolumn{3}{|l|}{ Floating Rates } \\
\hline $1 \mathrm{~m}$ LIBOR + 100 bps & $\$ 2.714$ & 1.25 \\
\hline \multirow[t]{2}{*}{ O/N Prime - 175 bps } & $\$ 1.179$ & 1.50 \\
\hline & $\$ 7.258$ & 2.14 \\
\hline \multicolumn{3}{|l|}{ California Public Employees' Retirement System } \\
\hline \multicolumn{3}{|l|}{ Floating Rates } \\
\hline $1 \mathrm{~m}$ LIBOR + 100 bps & $\$ 5.419$ & 1.25 \\
\hline Total and combined weighted average & $\$ 21.928$ & 1.76 \\
\hline
\end{tabular}

Source: Federal Reserve Board

Note: *Weighted averages in bold. 


\section{SUMMARY AND MARKET RATES ANALYSIS}

With the multitude of facilities created, excluding the five mentioned in the introduction, three programs comprised the bulk of the cumulative borrowing. ${ }^{22}$ These were the PDCF with 51 percent, TAF with 22 percent, and the TSLF with 11 percent. They would combine for 84 percent of the total borrowing. What is more, the PDCF and the TSLF were only accessible to primary dealers, meaning that there were no more than 20 banks worldwide that participated in these two facilities. ${ }^{23}$ These 20 banks contributed to 62 percent of the overall borrowing. Looking at the top eight individual cumulative borrowers, they would borrow roughly $\$ 11.5$ trillion dollars and/or Treasury securities with a combined weighted mean interest rate paid of 1.49 percent. Although, collectively, all the facilities analyzed above totaled approximately $\$ 17.7$ trillion in borrowing, three banks would borrow close to 40 percent of this total. These banks were Citigroup with $\$ 2.469$ trillion, Merrill Lynch with $\$ 2.256$ trillion, and Morgan Stanley with $\$ 2.069$ trillion. For all three of these banks, the majority of the borrowing came from the PDCF program. The rates for the top eight borrowers per facility are shown in Table 10. It must be noted, however, that all of the loans of these facilities, with the exception of TALF, have been repaid in full, with interest, in agreement with the terms of the facility.

Table 10 Rates for the top 8 borrowers

\begin{tabular}{|c|c|c|c|c|c|c|c|c|}
\hline \multicolumn{9}{|c|}{ Average Interest Rates of Top Eight Cumulative Borrowers Across All Facilities** } \\
\hline Facilities & $\begin{array}{l}\text { Citigroup } \\
\text { Inc. }\end{array}$ & $\begin{array}{l}\text { Merrill } \\
\text { Lynch }\end{array}$ & $\begin{array}{l}\text { Morgan } \\
\text { Stanley }\end{array}$ & AIG & BofA & $\begin{array}{l}\text { Bear } \\
\text { Stearns }\end{array}$ & Barclays & $\begin{array}{l}\text { Goldman } \\
\text { Sachs }\end{array}$ \\
\hline TAF & 1.931 & 2.870 & $\mathrm{n} / \mathrm{a}$ & $\mathrm{n} / \mathrm{a}$ & 0.451 & $\mathrm{n} / \mathrm{a}$ & 0.630 & $\mathrm{n} / \mathrm{a}$ \\
\hline ST OMO & 1.427 & 1.873 & 1.875 & $\mathrm{n} / \mathrm{a}$ & 1.804 & 2.650 & 1.748 & 1.248 \\
\hline TSLF & 0.321 & 0.574 & 0.591 & $\mathrm{n} / \mathrm{a}$ & 0.253 & 0.290 & 0.387 & 0.332 \\
\hline PDCF & 0.885 & 1.120 & 1.190 & $\mathrm{n} / \mathrm{a}$ & 0.949 & 2.373 & 2.291 & 1.781 \\
\hline
\end{tabular}

\footnotetext{
${ }^{22}$ These five, again, were the Central Bank Liquidity Swap Lines, the Money Market Investor Funding Facility, direct funding on future principle losses to Citigroup and Bank of America, and the Agency Mortgage-Backed Securities Program.

${ }^{23}$ Primary dealers serve as trading counterparties to the FRBNY in its implementation of monetary policy. The current list of primary dealers are: Bank of Nova Scotia; BMO Capital Markets Corp.; BNP Paribas Securities Corp.; Barclays Capital Inc.; Cantor Fitzgerald \& Company; Citigroup Global Markets Inc.; Credit Suisse Securities (USA) LLC; Daiwa Capital Markets America Inc.; Deutsche Bank Securities Inc.; Goldman, Sachs \& Co.; HSBC Securities (USA) Inc.; Jefferies \& Company, Inc.; J.P. Morgan Securities LLC; Merrill Lynch; Pierce, Fenner \& Smith Incorporated; Mizuho Securities USA Inc.; Morgan Stanley \& Co. LLC; Nomura Securities International, Inc.; RBC Capital Markets, LLC; RBS Securities Inc.; SG Americas Securities, LLC; and UBS Securities LLC.
} 


\begin{tabular}{|c|c|c|c|c|c|c|c|c|}
\hline CPFF & 2.711 & 1.865 & 1.588 & 2.619 & 1.822 & $\mathrm{n} / \mathrm{a}$ & 2.320 & 1.890 \\
\hline AMLF & 1.763 & $\mathrm{n} / \mathrm{a}$ & $\mathrm{n} / \mathrm{a}$ & $\mathrm{n} / \mathrm{a}$ & 2.118 & $\mathrm{n} / \mathrm{a}$ & $\mathrm{n} / \mathrm{a}$ & $\mathrm{n} / \mathrm{a}$ \\
\hline TALF & $\mathrm{n} / \mathrm{a}$ & $\mathrm{n} / \mathrm{a}$ & 2.698 & $\mathrm{n} / \mathrm{a}$ & $\mathrm{n} / \mathrm{a}$ & $\mathrm{n} / \mathrm{a}$ & $\mathrm{n} / \mathrm{a}$ & $\mathrm{n} / \mathrm{a}$ \\
\hline $\begin{array}{l}\text { Maiden Lane } \\
\text { I }\end{array}$ & $\mathrm{n} / \mathrm{a}$ & $\mathrm{n} / \mathrm{a}$ & $\mathrm{n} / \mathrm{a}$ & $\mathrm{n} / \mathrm{a}$ & $\mathrm{n} / \mathrm{a}$ & 0.810 & $\mathrm{n} / \mathrm{a}$ & $\mathrm{n} / \mathrm{a}$ \\
\hline $\begin{array}{l}\text { Maiden Lane } \\
\text { II \& III }\end{array}$ & $\mathrm{n} / \mathrm{a}$ & $\mathrm{n} / \mathrm{a}$ & $\mathrm{n} / \mathrm{a}$ & 1.335 & $\mathrm{n} / \mathrm{a}$ & $\mathrm{n} / \mathrm{a}$ & $\mathrm{n} / \mathrm{a}$ & $\mathrm{n} / \mathrm{a}$ \\
\hline RCF & $\mathrm{n} / \mathrm{a}$ & $\mathrm{n} / \mathrm{a}$ & $\mathrm{n} / \mathrm{a}$ & 4.950 & $\mathrm{n} / \mathrm{a}$ & $\mathrm{n} / \mathrm{a}$ & $\mathrm{n} / \mathrm{a}$ & $\mathrm{n} / \mathrm{a}$ \\
\hline SBF & $\mathrm{n} / \mathrm{a}$ & $\mathrm{n} / \mathrm{a}$ & $\mathrm{n} / \mathrm{a}$ & 2.362 & $\mathrm{n} / \mathrm{a}$ & $\mathrm{n} / \mathrm{a}$ & $\mathrm{n} / \mathrm{a}$ & $\mathrm{n} / \mathrm{a}$ \\
\hline $\begin{array}{l}\text { Cumulative } \\
\text { Borrowing* }\end{array}$ & $\$ 2,469$ & $\$ 2,256$ & $\$ 2,069$ & $\$ 1,047$ & $\$ 1,018$ & $\$ 976$ & $\$ 907$ & $\$ 836$ \\
\hline $\begin{array}{l}\text { Weighted } \\
\text { Average }\end{array}$ & .890 & 1.090 & 1.182 & 2.681 & .7999 & 2.348 & 1.493 & 1.412 \\
\hline
\end{tabular}

In almost all cases when comparing facilities rates against market rates, with the exception of the loans granted to AIG, they were either below or hovering around the market rates. See Figures 11-16 below. In many of these cases, the ffr would be the lowest rate over the time period of the facility. Yet, it must be emphasized that because this is the rate banks loan to one another short term (typically 24 hours), it was more than likely not utilized during the liquidity crisis. In addition, the rapidly decreasing ffr was not strictly the result of market forces, but of an active Fed intentionally pushing it down. Furthermore, with respect to AIG, it was perceived to be high risk if not insolvent; thus, not credible for loans in the view of other banks. 
Figure 11 TAF v. FFR, Discount, 1-M CD \& 1-M Eurodollar

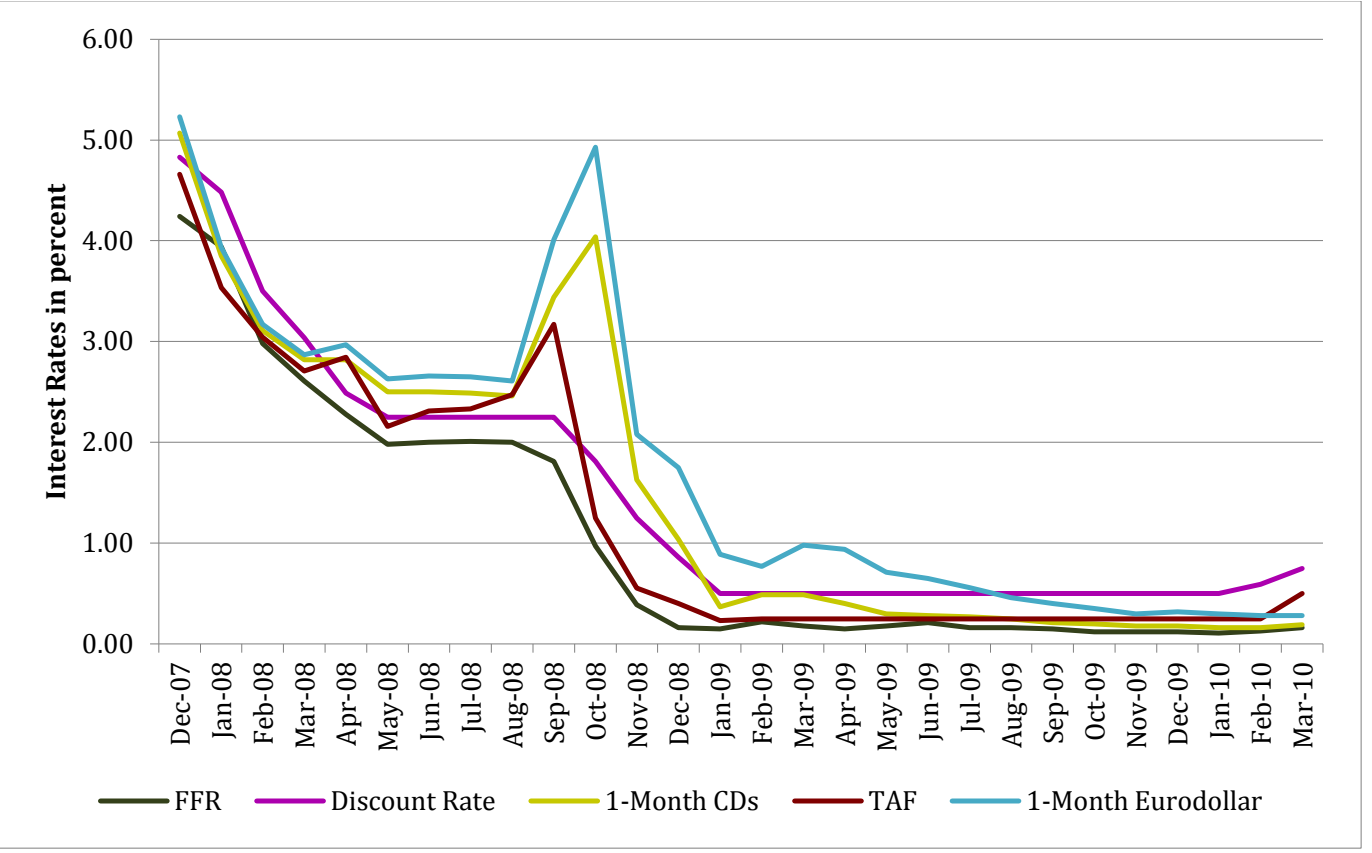

Source: Federal Reserve Board

Figure 12 TSLF v. 1-M \& 3-M Treasuries

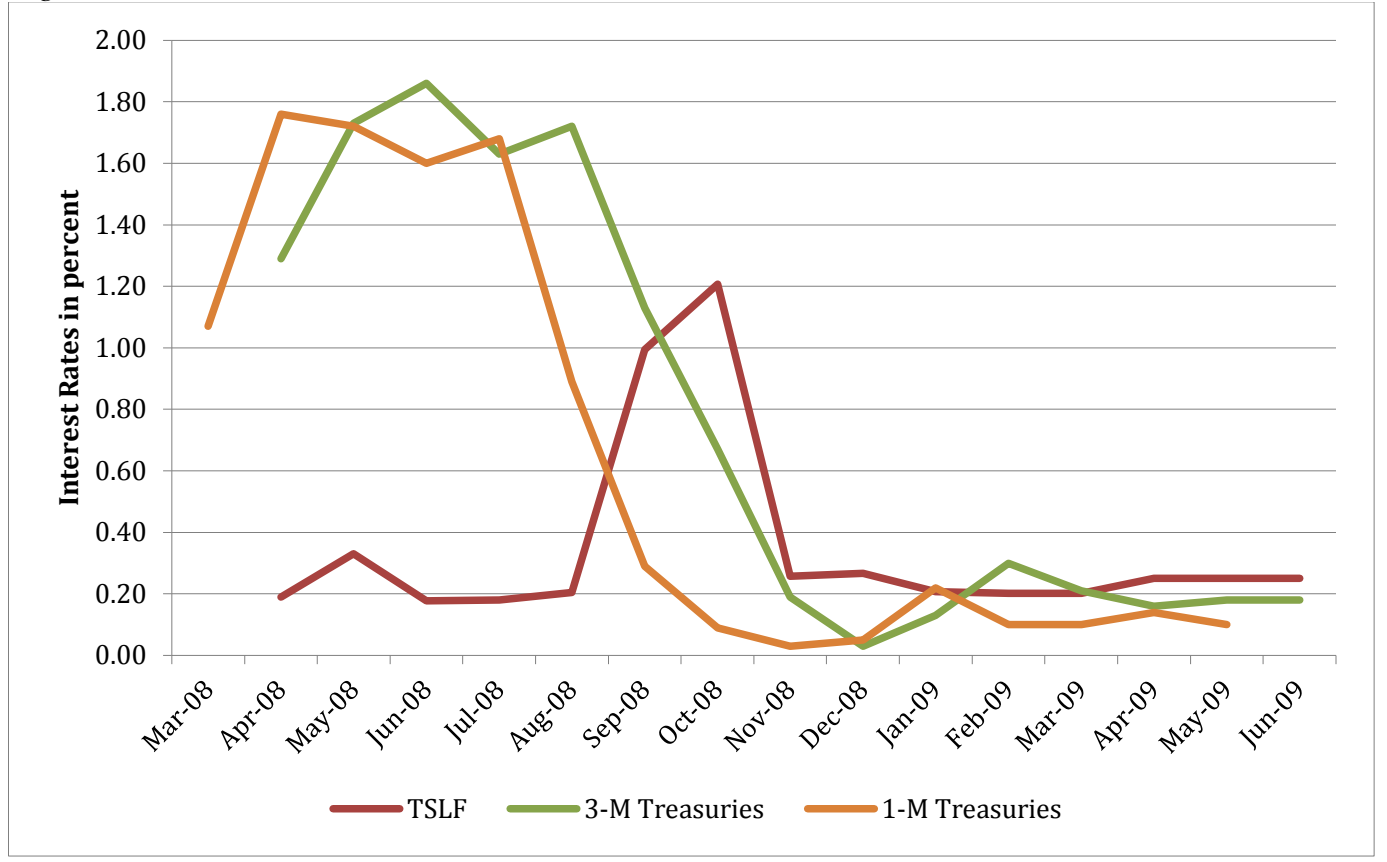

Source: Federal Reserve Board 
Figure 13 ST OMO \& PDCF v. Discount \& FFR

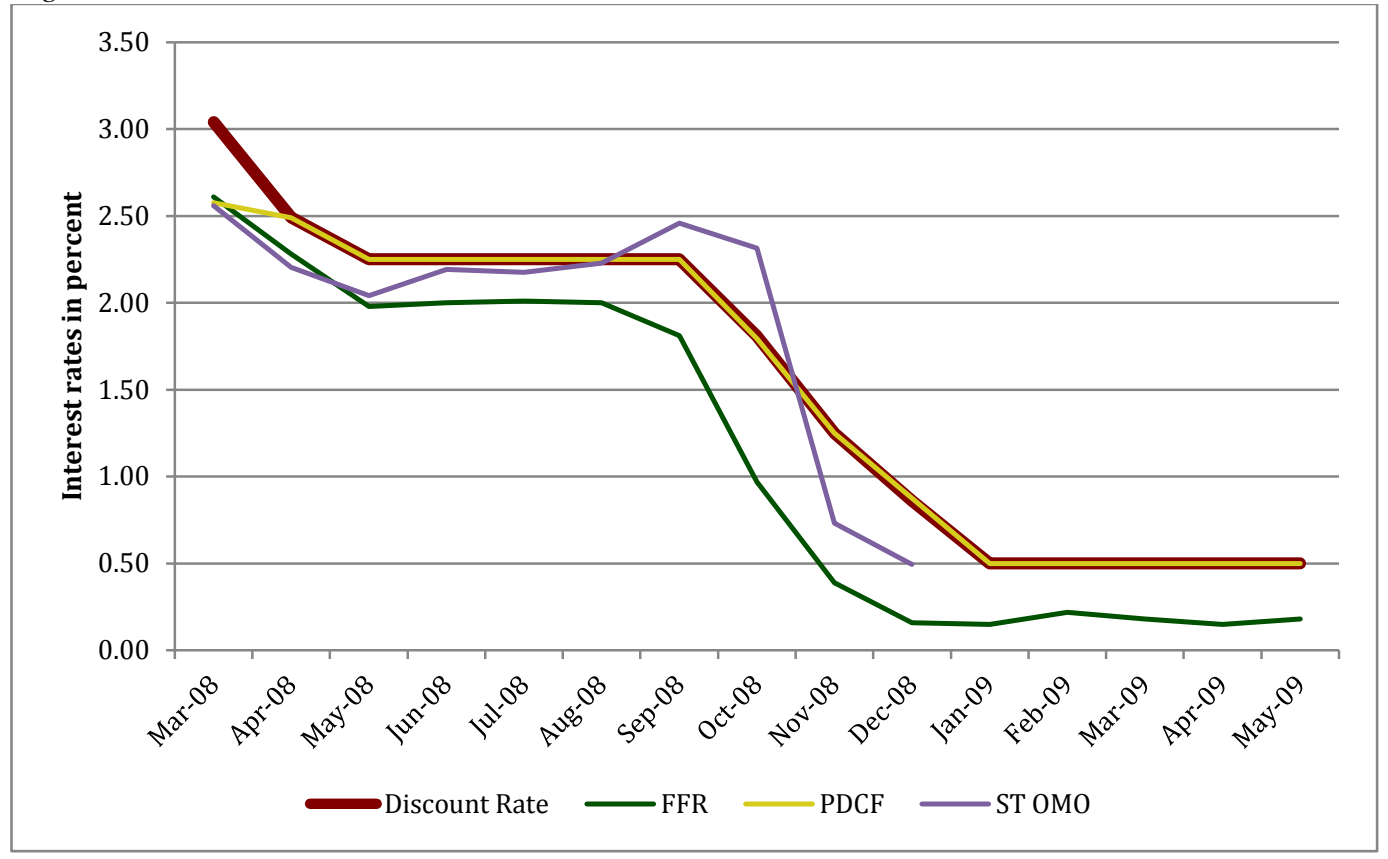

Source: Federal Reserve Board

Figure 14 Maiden Lanes, RCF, SBF v. FFR \& 1-M CD

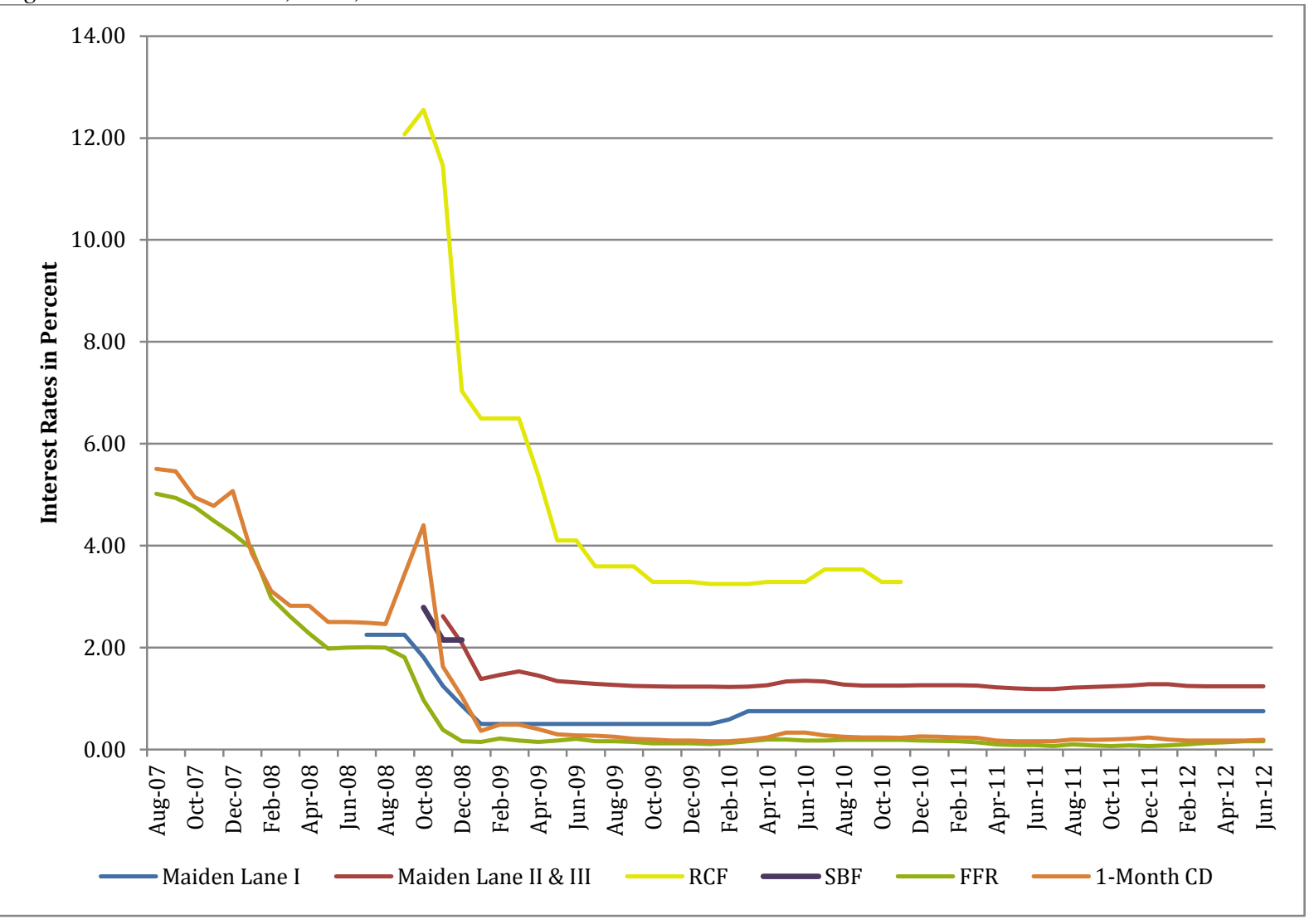

Source: Federal Reserve Board 
Figure 15 AMLF, CPFF v. Prime Rate \& CP

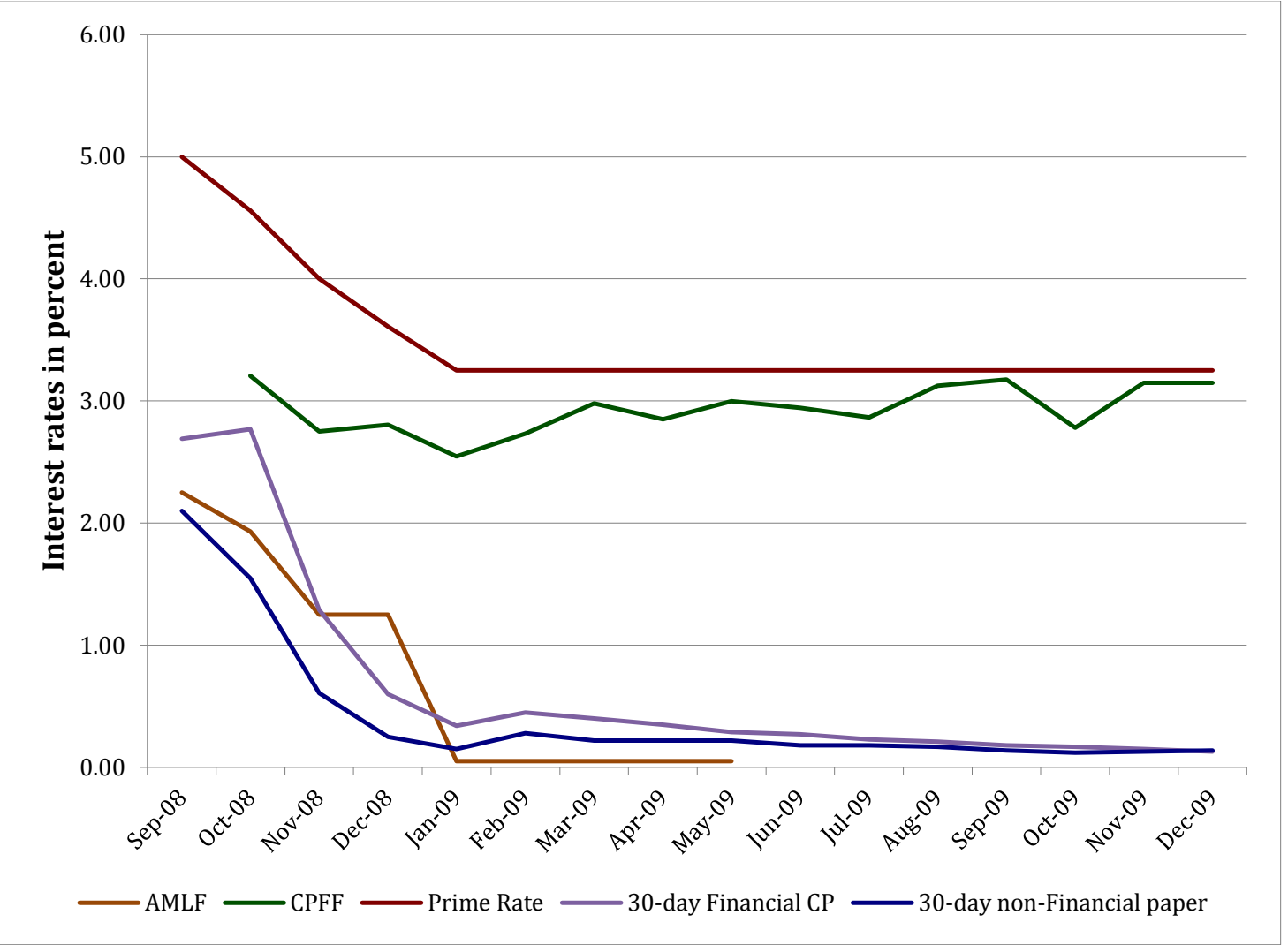

Source: Federal Reserve Board

Figure 16 TALF v. Prime Rate

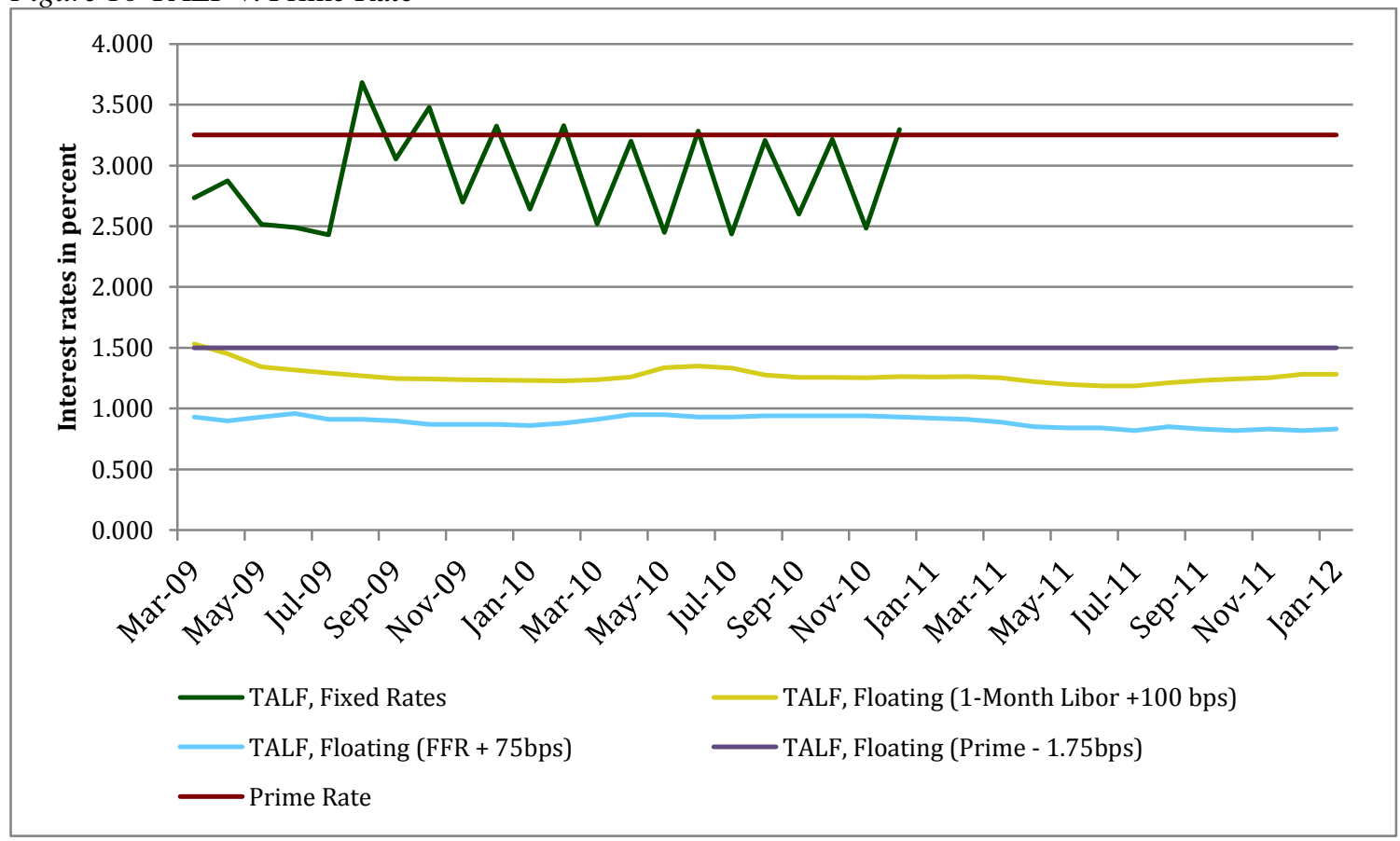

Source: Federal Reserve Board. 
As these charts illustrate, TAF, ST OMO, PDCF, TSLF, and AMLF were, on average, below or at the market rates with the exception of the ffr. Only CPFF and AIG would have lending rates above market rates. It is evident therefore, that the Fed, over the duration of the GFC, did not lend on average at penalty rates. Moreover, the average length of the facilities, excluding ST OMO (which was not designed as a standing facility), was over three years. If we exclude the individual support to Bear and AIG, the average length is still close to two years (22 months).

\section{CONCLUSION}

Fed intervention in times of liquidity crises is a necessity of the banking system. In such an event, it should stand ready to lend to banks and fulfill its role of LOLR, but it should not stand ready to lend without penalty rates, without good collateral, and for sustained periods of time. Multiple problems arise when the Fed engages in such action-moral hazard being first among them. Secondly, the crisis becomes an issue of solvency, not liquidity. Lending at low rates to insolvent banks for a sustained period of time (with an average of almost two years) can have the effect of increasing bank profitability. It is of little wonder that the crisis was tamed after the Fed bought $\$ 1.25$ trillion in arguably toxic assets (MBSs). By departing from its traditional function as an LOLR to depository institutions, the Fed engaged in unconventional acts and effectively went from aiding markets to making markets. By doing so, it not only circumvented the normal functioning of financial markets but it also circumvented the democratic process. ${ }^{24}$ Lending at or below market rates, allowing banks to negotiate these rates through auctions, and rescuing insolvent banks has validated not only unstable banking instruments and practices but also has set the stage for an even greater crisis. ${ }^{25}$

In conclusion, it is evident that Bagehot's principles of lending at penalty rates during liquidity crises were not adhered to. In addition, the extraordinary lengths of the facilities are themselves not consistent with a liquidity crisis. Whether Bagehot's policies are sound, it is clear that his name should not be invoked as a justification for the Fed's LOLR intervention.

${ }^{24}$ See Todd (1988).

${ }^{25}$ See Minsky (1986). 


\section{REFERENCES}

Adrian, T., K. Kimbrough, and D. Marchioni. 2011. "The Federal Reserve's Commercial Paper Funding Facility.” FRBNY Economic Policy Review 17(1): 25-39.

Bagehot, W. 1873. Lombard Street: A Description of the Money Market. London, UK: S. King and Co.

Bernanke, B. S. 2008. "Liquidity Provision by the Federal Reserve," Speech at the Federal Reserve Bank of Atlanta Financial Markets Conference. Sea Island, Georgia, May 13. http://www.federalreserve.gov/newsevents/speech/bernanke20080513.htm.

- 2010. Federal Reserve's Exit Strategy. Testimony before the Committee on Financial Services, February 10.

http://www.federalreserve.gov/newsevents/testimony/bernanke20100210a.htm

—. 2011. Memo to the Senate Banking Committee. December 6. http://www.federalreserve.gov/generalinfo/foia/emergency-lending-financial-crisis20111206.pdf'

Bloomberg News. 2011. "Bloomberg News Responds To Bernanke Criticism Of US BankRescue Coverage." Bloomberg News, December 7. http://www.bloomberg.com/news/2011-12-06/bloomberg-news-responds-to-bernankecriticism.html

Cecchetti, S. and P. Disyatat. 2010. "Central Bank Tools and Liquidity Shortages," FRBNY Economic Policy Review 16(1): 29-42.

Crockett, A. 1997. The Theory and Practice of Financial Stability. Princeton, NJ: Princeton University Press.

Federal Reserve. 2009. 95th Annual Report, 2008. June.

Federal Reserve Bank of New York (FRBNY). 2012. "New York Fed Responds to Congressional Request for Information on Barclays - LIBOR Matter." News and Events, July 12 .

http://www.newyorkfed.org/newsevents/news/markets/2012/Barclays_LIBOR_Matter.ht $\mathrm{ml}$

Felkerson, J. A. 2011. "Bail-out Bombshell: Fed 'Emergency’ Bank Rescue Totaled \$29

Trillion Over Three Years." AlterNet, December 15. http://www.alternet.org/story/153462/bail-

out_bombshell\%3A_fed_\%22emergency\%22_bank_rescue_totaled_\%2429_trillion_ove r_three_years/

- 2012 "A Detailed Look at the Fed's Crisis Response by Funding Facility and Recipient." Public Policy Brief No. 123. Annandale-on-Hudson, NY: Levy Economics Institute of Bard College. http://www.levyinstitute.org/pubs/ppb_123.pdf 
Felsenthal, M. 2011. "Bernanke to the Hill: Flawed Reporting on Fed Loans.” Reuters, December 6. http://www.reuters.com/article/2011/12/07/us-usa-fed-lendingidUSTRE7B51W420111207

Goodhart, C. and G. Illing. 2002. Financial Crises, Contagion and the Lender of Last Resort. Oxford, UK: Oxford University Press.

Government Accountability Office (GAO). 2011. "Federal Reserve System: Opportunities Exist to Strengthen Policies and Processes for Managing Emergency Assistance." United States Government Accountability Office Report to Congressional Addressees, July. http://www.gao.gov/assets/330/321506.pdf

Ivry, B., B, Keoun, and P. Kuntz. 2011. "Secret Fed Loans Gave Banks \$13 Billion Undisclosed to Congress." Bloomberg News, November 27. http://www.bloomberg.com/news/201111-28/secret-fed-loans-undisclosed-to-congress-gave-banks-13-billion-in-income.html

Minsky, H. 1986. Stabilizing an Unstable Economy. New York: McGraw-Hill.

Moe, T. 2012. “Terms and Conditions for Central Bank Liquidity Support.” Forthcoming.

Solow, R. 1982. "On the Lender of Last Resort." In C. P. Kindleberger and J-P. Laffargue (Eds.), Financial Crises: Theory, History and Policy. Cambridge, UK: Cambridge University Press.

Ricks, M. 2011. "Regulating Money Creation After the Crisis." Harvard Business Law Review 1: $75-143$.

Thornton, D. L. 2008. "Walter Bagehot, the Discount Window, and TAF." Federal Reserve Bank of St. Louis Economic Synopses. 27: 1-2.

Thorton, H. 1802. An Enquiry into the Nature and Effects of the Paper Credit of Great Britain. London, UK: Hatchard.

Todd, W. F. 1988. "Lessons of the Past and Prospects for the Future in Lender of Last Resort Theory." Working Paper 8805. Cleveland, OH: Federal Reserve Bank of Cleveland.

- 2002. "Central Banking in a Democracy: The Problem of the Lender of Last Resort." In P. A. McCoy (Ed.), Financial Modernization after Gramm-Leach-Bliley. Newark, NJ: Lexis/Nexis Matthew Bender.

Wray, L. R. 2011. “The \$29 Trillion Bail-Out: A Resolution and Conclusion.” EconoMonitor, December 14. http://www.economonitor.com/lrwray/2011/12/14/the-29-trillion-bail-outa-resolution-and-conclusion/

- 2012. "Improving Governance of the Government Safety Net in Financial Crises." Research Project Report, April 9. http://www.levyinstitute.org/pubs/rpr_04_12_wray.pdf 